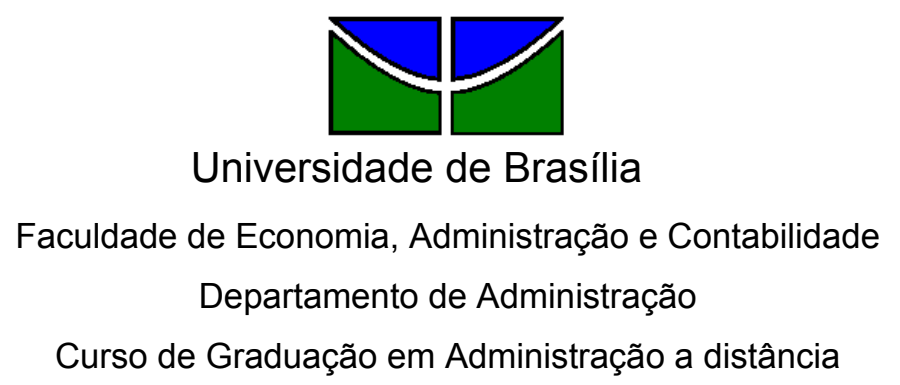

JOSÉ SÉRGIO DE JESUS

\title{
MARKETING EDUCACIONAL: Uma análise dos fatores que influenciam a escolha de uma faculdade
}

$$
\begin{gathered}
\text { Brasília - DF } \\
2010
\end{gathered}
$$




\section{JOSÉ SÉRGIO DE JESUS}

\section{MARKETING EDUCACIONAL: Uma análise dos fatores que influenciam a escolha de uma faculdade}

Monografia apresentada a Universidade de Brasília (UnB) como requisito parcial para obtenção do grau de Bacharel em Administração.

Professor Supervisor: Msc. Pedro Henrique Albuquerque

Professora Orientadora: Helena Célia de Souza Sacerdote

Brasília - DF

2010 
Jesus, José Sérgio de.

Marketing educacional: uma análise dos fatores que influenciam a escolha de uma faculdade/ José Sérgio de Jesus. - Brasília, 2010

$63 \mathrm{f}$. : il.

Monografia (bacharelado) - Universidade de Brasília, Departamento de Administração - EaD, 2010.

Orientadora: Professora Helena Célia de Souza Sacerdote. Supervisor: Msc Pedro Henrique Albuquerque, Departamento de Administração.

1. Marketing. 2. Marketing educacional. 3. Imagem, marca e criação de valor. I. Título. 


\title{
JOSÉ SÉRGIO DE JESUS
}

\section{MARKETING EDUCACIONAL: Uma análise dos fatores que influenciam a escolha de uma faculdade}

\begin{abstract}
A Comissão Examinadora, abaixo identificada, aprova o Trabalho de Conclusão do Curso de Administração da Universidade de Brasília do aluno
\end{abstract}

\author{
José Sérgio de Jesus \\ Helena Célia de Souza Sacerdote \\ Professora-Orientadora
}

Helena Célia de Souza Sacerdote Professora-Examinadora
Msc. Pedro Henrique Albuquerque

Professor-Examinador 


\section{AGRADECIMENTOS}

Agradeço mais esta conquista a minha esposa, companheira de todos os momentos, Maria Sunes Pereira de Jesus, pelo permanente apoio em minha jornada acadêmica.

Meus sinceros agradecimentos à Professora orientadora Helena Célia de Souza Sacerdote pelas preciosas orientações e dedicação aos alunos. 


\section{RESUMO}

O estudo objetiva verificar os fatores que influenciam a clientela regularmente matriculada no ano de 2010, na escolha pela Escola Superior Professor Paulo Martins - Faculdade ESPAM, situada em Sobradinho, no Distrito Federal. Foi realizada a revisão da literatura, que culminou no referencial teórico sobre marketing, serviços, imagem, marca e criação de valor e marketing educacional. Foi realizada a coleta de dados por meio de questionário em uma amostra de 324 respondentes, tendo a devolução de 261 questionários. Os dados foram tabulados e analisados visando definir o perfil socioeconômico da clientela; as necessidades da clientela por educação superior; a percepção da clientela quanto aos valores e imagem da faculdade; deficiências da faculdade sob a ótica da clientela; e os indicadores que influenciam a clientela na escolha por uma faculdade. Os resultados são discutidos e interpretados, concluindo que a faculdade deve reforçar o seu marketing com foco na sua localização, qualidade dos cursos e corpo docente.

Palavras-chave: Marketing. Marketing educacional. Imagem, marca, criação de valor. 


\section{LISTA DE ILUSTRAÇÕES}

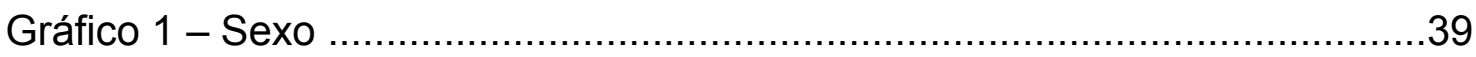

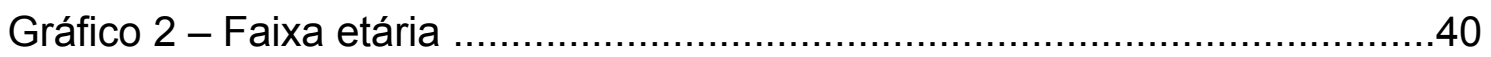

Gráfico 3 - Atividade remunerada ..................................................41

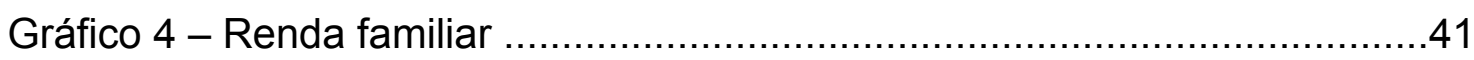

Gráfico 5 - Forma de custeio dos estudos ...........................................42

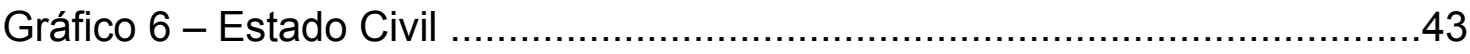

Gráfico 7 - Local de moradia dos alunos .................................................43 


\section{LISTA DE QUADROS}

Quadro 1 - Média dos indicadores de necessidades da clientela.........................44

Quadro 2 - média da percepção quanto à imagem e valores.............................48

Quadro 3 - média da percepção das deficiências da faculdade .............................50

Quadro 4 - média dos indicadores que influenciam a escolha da faculdade...........52 


\section{SUMÁRIO}

1 INTRODUÇÃO

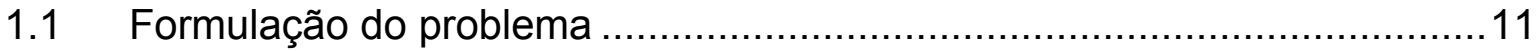

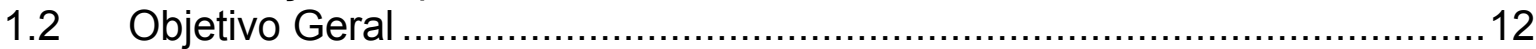

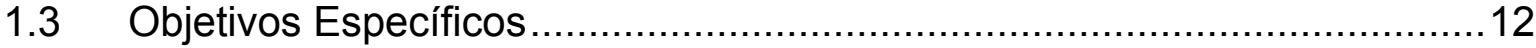

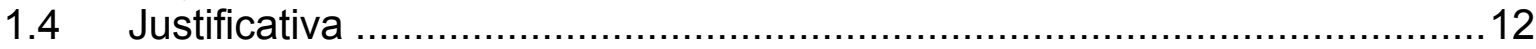

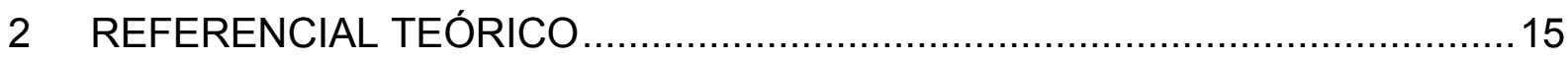

2.1 Marketing: uma breve análise conceitual ...........................................15

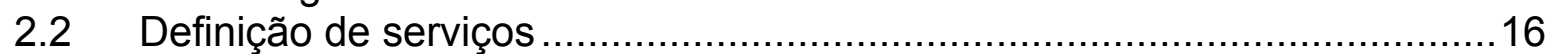

2.3 Imagem, Marca e Criação de Valor......................................................17

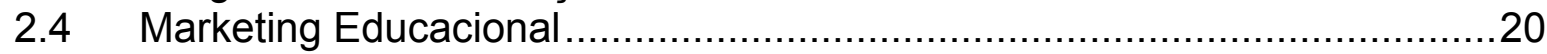

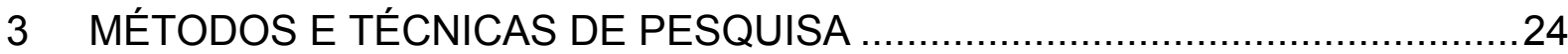

3.1 Tipo e descrição geral da pesquisa..................................................24

3.1.1 Abordagens Ontológica e Epistemológica ………..........................24

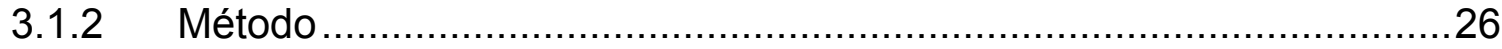

3.2 Caracterização da organização, setor ou área ....................................27

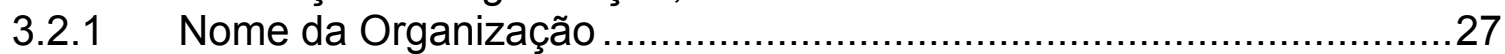

3.2.2 Registro e situação legal:.........................................................27

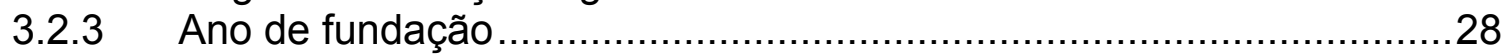

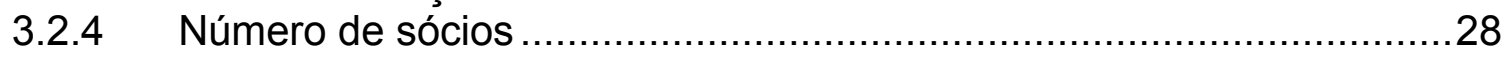

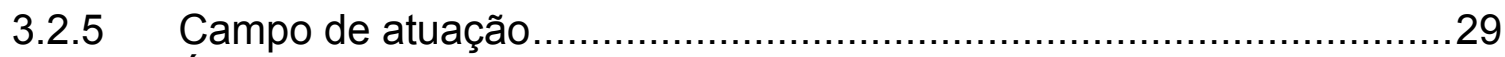

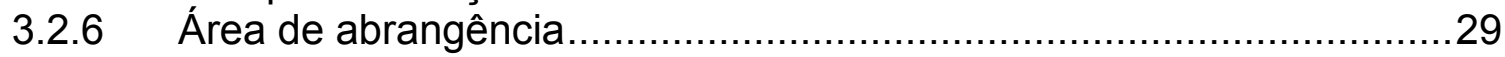

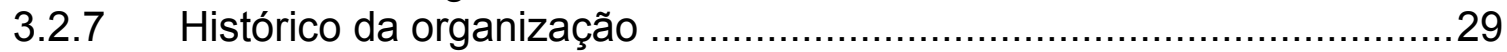

3.2.8 Estrutura organizacional e administrativa ……..................................30

3.2.9 Cursos oferecidos pela ESPAM:................................................

3.3 População e amostra ou participantes do estudo ....................................31

3.4 Caracterização dos instrumentos de pesquisa .......................................32

3.5 Procedimentos de coleta e de análise de dados .........................................34

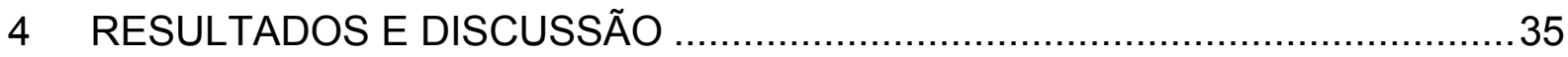

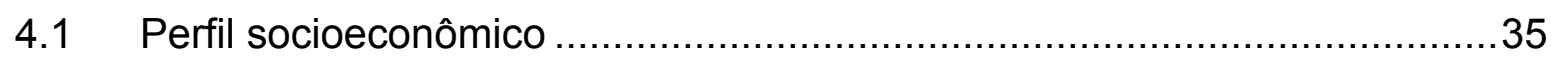

4.2 Necessidades da clientela por educação superior ...................................41

4.3 Percepção da clientela quanto aos valores e imagem da faculdade ..........44

4.4 Deficiências da faculdade sob a ótica da clientela ..................................47

4.5 Indicadores que influenciam a clientela na escolha por uma faculdade......49

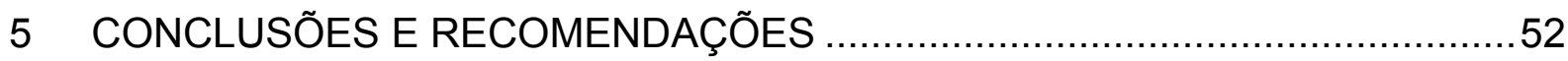

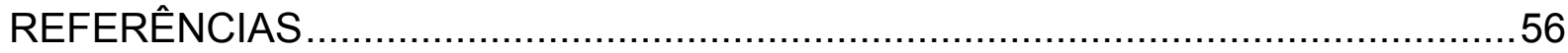

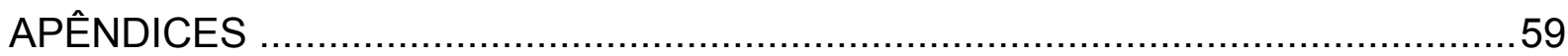




\section{INTRODUÇÃO}

A Educação Superior brasileira atual, como a maioria dos segmentos de mercado, está inserida em um ambiente extremamente competitivo. Neste contexto estão as Instituições de Ensino Superior (IES), que são desafiadas diuturnamente a manter a sua sustentabilidade. No momento, ações meramente operacionais não conseguem garantir um desempenho superior destas organizações no mercado.

Segundo Braga e Monteiro (2005), foi-se o tempo que as IES concorriam apenas com outras IES presentes na mesma região geográfica. Atualmente, estas organizações começam a sofrer a concorrência de diversos novos entrantes, como a educação a distância (EAD), cursos livres (universidades abertas), universidades corporativas, universidades setoriais e as instituições de intermediação.

Este cenário se definiu a partir do final da década de 1990, quando o Ministério da Educação - MEC - alterou a sua política de expansão do ensino superior no Brasil, facilitando a implementação de Instituições de Ensino Superior IES - por meio de uma regulamentação mais permissiva, em que facilitava a abertura de faculdades, bem como a oferta de novas metodologias, como a educação a distância.

Com isso, houve, no Distrito Federal, a explosão do mercado de ensino superior com a ampliação exacerbada da oferta, criando uma nova realidade no setor, pois houve a ruptura da centralização da oferta em poucas instituições.

Assim, praticamente em todas as regiões do Distrito Federal foram criadas faculdades, com um perfil diferenciado das antigas IES que estavam centralizadas em Brasília, o que atendeu a uma clientela que desejava cursar uma graduação, mas era impedida pelos preços excludentes das mensalidades, ou pela distância no deslocamento até a área central.

As faculdades recém-criadas tiveram crescimento rápido ao atender esta demanda reprimida, o que motivou a abertura de novas IES e continuidade da expansão do setor. 
Além disso, com o credenciamento de instituições com oferta de cursos superiores na metodologia de educação a distância, a partir de 2003, houve, ainda, a entrada no mercado de um novo concorrente, com uma rápida expansão, que pela falta de regulamentação inicial, provocou a abertura indiscriminada de pólos de $E A D^{1}$, sem qualquer estrutura física ou acadêmica, mas que, de forma predatória, abalou a procura pelas IES de educação presencial.

Entretanto, atendida essa demanda inicial, houve uma retração no mercado em razão do excesso de vagas ofertadas e o desproporcional crescimento da procura, tendo em vista que os egressos ${ }^{2}$ do Ensino Médio, em sua maioria de escolas públicas, pertencentes às classes sociais $C, D$ e $E$ ainda não terem renda suficiente para o custeio de seus estudos.

Por outro lado, o público ideal para qualquer faculdade, ou seja, os pertencentes às classes $A$ e $B$, manteve-se fiel às instituições tradicionais ou ingressou na universidade pública.

Além disso, algumas "aventuras" na área mostraram-se frustradas, pelo despreparo dos gestores, que não perceberam as peculiaridades do ensino superior e estabeleceram estratégias equivocadas para os seus negócios.

O fechamento de faculdades, a instabilidade de outras e a má reputação de algumas influenciaram sobremaneira o cenário, que se apresenta totalmente diferenciado do início da década.

Diante disso, para o mercado atual de ensino superior no Distrito Federal são observados como fatores críticos de sucesso a credibilidade da instituição, com a conquista de bons indicadores de qualidade exigidos pelo Ministério da Educação, como o Exame Nacional de Desempenho do Estudante ENADE, Índice Geral de Cursos - IGC, Conceito Preliminar de Curso - CPC e as avaliações externas realizadas pelo MEC, complementada por um corpo docente titulado e competente.

Outro fator determinante, em razão da concorrência acirrada entre as IES, é a política de preços de mensalidades e de descontos, com a implementação de programas que facilitem o acesso das classes $C$ e $D$ ao ensino superior, vez que

\footnotetext{
${ }^{1}$ Pólos de apoio para encontros presenciais, estudos dirigidos, avaliação e tutoria.

${ }^{2}$ Ex-aluno
} 
esta parcela da população, com o crescimento econômico evidenciado nos últimos anos, aumentou a sua renda per capita, possibilitando o seu ingresso na faculdade.

Um indicador também importante é a localização da IES, sua estrutura física, sua política de atendimento, gestão compartilhada com tratamento individualizado ao discente ${ }^{3}$ e atendimento de suas necessidades.

Por fim, observa-se, neste contexto, que o morador do Distrito Federal possui culturalmente uma propensão para os estudos, conforme evidenciado no Censo da Educação de $2009^{4}$, em que o número de matrícula no Ensino Médio na rede pública de ensino do Distrito Federal, clientela potencial das IES, ampliou de 65.196 alunos para 78.213 alunos, que corresponde a um aumento de $20 \%$ (vinte por cento) em 2009.

Diante disso, a pesquisa pretende analisar o Marketing Educacional, especialmente o posicionamento da marca e percepção da imagem de uma IES isolada, regionalizada e de pequeno porte, situada no Distrito Federal, que apenas oferece curso de graduação na modalidade presencial.

\subsection{Formulação do problema}

Diante da acirrada disputa pelo mercado de ensino superior privado no Distrito Federal, torna-se necessária a investigação científica da posição mercadológica das IES que se situam na região periférica do Distrito Federal, que buscam sobreviver à forte concorrência dos grupos educacionais.

Portanto, face ao cenário contextualizado, esta pesquisa buscará responder ao seguinte questionamento:

Quais os fatores que influenciam a clientela na escolha por uma faculdade situada em cidade satélite no Distrito Federal?

\footnotetext{
${ }^{3}$ Aluno matriculado na Instituição de Educação Superior.

${ }^{4}$ Disponível em www.inep.gov.br/superior/censosuperior/
} 


\subsection{Objetivo Geral}

Verificar os fatores que influenciam a clientela, regularmente matriculada no ano de 2010, na escolha pela Escola Superior Professor Paulo Martins - Faculdade ESPAM, situada em Sobradinho, no Distrito Federal.

\subsection{Objetivos Específicos}

- Identificar o perfil sócio-econômico da clientela da Faculdade ESPAM;

- Verificar a necessidade da clientela por educação superior, bem como os cursos desejados;

- Verificar a percepção da clientela quanto à imagem e valores da Faculdade ESPAM;

- Compreender as deficiências da Faculdade ESPAM sob a ótica da clientela;

- Analisar os indicadores que influenciam a clientela na escolha por uma faculdade.

\subsection{Justificativa}

A escolha pelo tema deu-se em razão de a área de educação superior ser o campo de atuação profissional do pesquisador nos últimos 15 anos, o que motivou o interesse pelo aprofundamento do estudo sobre o posicionamento da marca das Instituições de Educação Superior - IES, no competitivo mercado do Distrito Federal.

A trajetória profissional do autor, como gestor de IES, possibilitou perceber que na última década ocorreu uma rápida mudança no setor, em que as faculdades eram referência como centro de conhecimento e se transformaram em uma organização que deve captar clientes, preocupar-se com a sua satisfação, fidelizá-lo e oferecer um produto de qualidade. 
Face a este contexto, há a necessidade de compreender como os clientes percebem os serviços oferecidos por uma IES, identificando os principais fatores que influenciam na escolha por uma faculdade.

Por outro lado, é oportuno salientar que o foco de interesse da pesquisa é a investigação destes fatores em uma IES que não tenha a tradição daquelas pioneiras, que se situam na área central de Brasília, vez que estas já têm um posicionamento no mercado e têm foco em uma clientela de maior poder aquisitivo.

Assim, ao definir como objeto da pesquisa uma IES que foi criada no momento da expansão da educação superior brasileira, em que, no Distrito Federal, houve um aumento de $300 \%$ no número de faculdades credenciadas pelo Ministério da Educação, em apenas 12 anos, sendo que 70\% delas estão localizadas em cidades satélites ${ }^{5}$, destaca-se a relevância social do trabalho científico, tendo em vista que os resultados obtidos contribuirão, sem dúvida, para a estratégia de marketing destas faculdades que buscam a sobrevivência no mercado.

Ressalta-se, também, a forte tendência de concentração do setor em poucos grupos gestores, em um processo de incorporação iniciado em 2007, sendo que houve a entrada de investidores externos no Distrito Federal, bem como o movimento expansivo de grupos do próprio DF que promoveram a aquisição de algumas destas pequenas faculdades isoladas, com o ganho substancial da marca.

Desta forma, justifica-se socialmente a pesquisa tanto para a compreensão do perfil da clientela residente nas cidades satélites, ao identificar as suas necessidades, percepção quanto à imagem de uma faculdade, as deficiências percebidas desta faculdade e os indicadores que influenciam a escolha, ou seja, possibilita a segmentação de um mercado específico, como, para a faculdade, permite conhecer estes dados, o que facilitará o seu planejamento estratégico de marketing, podendo contribuir para sua consolidação e para a sua expansão, podendo ser aplicável em outras IES com as mesmas características.

Por fim, a importância acadêmica do estudo está na ampliação dos estudos no campo do marketing educacional que é bastante carente na literatura,

\footnotetext{
${ }^{5}$ www.inep.gov.br
} 
sendo possível o aprofundamento no tema, contribuindo para a produção científica e despertar o interesse acadêmico por esta área de estudo. 


\section{REFERENCIAL TEÓRICO}

\subsection{Marketing: uma breve análise conceitual}

Para Kotler e Keller (2006), o marketing compreende identificar e satisfazer as necessidades humanas e sociais, ou seja, objetiva suprir as necessidades de forma lucrativa, sendo que a administração de marketing é conceituada como a arte a ciência da escolha de mercados-alvos e da captação, manutenção e fidelização dos clientes por meio da criação, da entrega e da comunicação de um valor superior para o cliente.

Magalhães e Sampaio (2007) afirmam que o conjunto de atividades do marketing fundamenta-se no marketing como filosofia dos negócios com foco no atendimento das necessidades do cliente.

O marketing enfatiza a orientação ao cliente e a coordenação das atividades de marketing para alcançar os objetivos de desempenho da organização, baseado em três crenças: a) todo planejamento e as operações devem ser orientados para os clientes; b) todas as atividades de marketing em sua organização precisam ser coordenadas; e c) o marketing coordenado e orientado ao cliente é essencial para atingir os objetivos de desempenho da organização (ETZEL ET AL., 2001).

Las Casas (2008, p. 24) define marketing como:

A área de conhecimento que engloba todas as atividades concernentes às relações de troca, orientadas para a satisfação dos desejos e necessidades dos consumidores, visando alcançar determinados objetivos da organização ou indivíduos e considerando sempre o ambiente de atuação e o impacto que estas relações causam no bem-estar da sociedade (LAS CASAS, 2008, p. 24).

Para Etzel et al (2001), a administração deve envolver um mix de marketing, que é a combinação de um produto/serviço, como ele é distribuído e promovido o seu preço. Assim, para o autor, devem-se considerar os quatro fatores: produto, preço, distribuição e promoção. 


\subsection{Definição de serviços}

O setor de serviços passa por uma drástica mudança, o que afeta diretamente o modo de vida das pessoas, vez que novos serviços são lançados de forma contínua, na busca da satisfação das necessidades existentes e outras que surgem constantemente (LOVERLOCK e WIRTZ, 2006).

Kotler e Keller (2006, p. 397) conceituam serviço como "qualquer ato ou desempenho, essencialmente intangível, que uma parte pode oferecer a outra e que não resulta na propriedade de nada".

Loverlock e Wirtz (2006) afirmam que um serviço é um ato ou desempenho oferecido por uma parte à outra, sendo, portanto, uma atividade econômica que cria valor e proporciona benefícios a clientes em horários e locais específicos, efetuando uma mudança desejada em quem recebe os serviços, ou em seu nome.

Por sua vez, Etzel et al (2001, p. 523) definem serviço como "atividades intangíveis identificáveis que são o objeto principal de uma transação, designados para prover a satisfação de um desejo do cliente".

Características essenciais dos serviços são apontadas por Loverlock e Wirtz (2006), como:

1) Clientes não obtêm propriedade de serviços;

2) Produtos que são serviço são efêmeros e não podem ser estocados;

3) Elementos intangíveis dominam a criação de valor;

4) Clientes podem ser envolvidos no processo de produção;

5) Muitos serviços são difíceis de ser avaliados por clientes;

6) O fator tempo adquire grande importância; e

7) Canais de distribuição assumem formas diferentes.

Os autores apontam que, para capturar a natureza distintiva dos desempenhos específicos de serviços, é necessário modificar o mix de marketing (Produto, Preço, Distribuição e Promoção), ampliando-o, sendo acrescentados mais três elementos, que ficam assim definidos: 
a) Elementos do produto - aspectos de desempenho de serviço que tenham potencial para criar valor para os clientes.

b) Lugar (praça) e hora - rapidez e conveniência de lugar e horário para o cliente são importantes determinantes na estratégica de entrega de serviços.

c) Promoção e educação - atividades promocionais influenciam a escolha da marca e incentivos são usados para atrair os clientes à compra do serviço.

d) Preço e outros desembolsos do usuário - As estratégias não se limitam à definição de preços, devendo procurar minimizar outros desembolsos, que incluem custos monetários adicionais (como despesas de viagem até o local do serviço), dispêndio de tempo, esforço físico e mental indesejados e exposição a experiências sensoriais negativas.

e) Ambiente físico - as evidências físicas precisam ser gerenciadas de forma cuidadosa, vez que elas causam impacto profundo sobre as impressões dos clientes.

f) Processo - processos precários dificultam a boa execução de serviços pelo pessoal da linha de frente, resultando em baixa produtividade e maior probabilidade de falhas no serviço.

g) Pessoas - a qualidade do serviço é frequentemente avaliada baseando-se nas interações dos clientes com o pessoal de linha de frente, sendo que devem ser dedicados esforços significativos ao recrutamento, treinamento e motivação dos colaboradores.

\subsection{Imagem, Marca e Criação de Valor}

Segundo Magalhães e Sampaio (2007), Al Ries e Jack Trout, em 1972, conceituaram a estratégia de posicionamento que é a ocupação de um determinado espaço conceitual na mente dos consumidores com um elemento diferenciador de um produto ou serviço. Um mesmo pode adquirir relevância de valor superior ao ser apresentado de modo único entre os concorrentes, mesmo em oposição a um líder. 
Para os autores as etapas previstas para definição do posicionamento são: i) encontrar um nicho estratégico de mercado; ii) avaliar forças e recursos; iii) desenhar a arquitetura do posicionamento (relevância, competitividade, singularidade, defensabilidade, rentabilidade, expansão da franquia da marca, sustentabilidade); e iv) fazer a engenharia do posicionamento.

A visão reconstrutivista do marketing, proposta por Kim e Maugborne, em 1997, considera que o desafio estratégico deve ir além das estruturas e das fronteiras dos mercados existentes, pois eles podem ser um paradigma questionável, vez que a demanda adicional existe em estado latente e em grande parte inexplorada, devendo ser convertida a demanda potencial em demanda real, 0 que pode ocorrer para a criação de valor inovador para o mercado consumidor (MAGALHÃES E SAMPAIO, 2007).

De Toni e Schuler (2007, p. 3) conceituam que "imagens são representações, impressões, convicções e redes de significados de um objeto (produto/marca, corporação, loja) armazenado na memória de forma holística "(DE TONI E SCHULER, 2007, p. 3). Por sua vez, os autores definem que "imagem de produto é uma construção sistêmica, podendo ser configurada a partir de um sortimento de elementos funcionais, simbólicos, cognitivos e emocionais" (DE TONI E SCHULER, 2007, p. 4).

Os autores sintetizam que quanto mais importante um produto for para o indivíduo (envolvimento), maior tenderá a ser a rede de significados associada a ele.

A gestão com foco na marca é uma nova visão estratégica, pois a marca o é ponto central da gestão organizacional, com o alinhamento de produtos, processos, ações e comunicação com foco em uma mensagem objetiva e com relevância para o cliente (COLOMBO, 2005).

Magalhães e Sampaio (2007) apresentam um novo conceito, relacionado ao marketing, o branding, que se trata do conjunto das teorias e práticas de construção e gestão de marcas capaz de otimizar o uso de recursos e ferramentas de comunicação, que aumenta o valor da marca.

Kotler e Keller (2006) identificam o branding como a dotação dos produtos e serviços com poder de uma marca, ou seja, cria diferenças a partir do 
momento em que para se colocar uma marca em um produto é necessário ensinar aos clientes "quem" é o produto, bem como a "que" ele se presta e "por que" o consumidor deve ser interessar por ele.

Woodruff (1997, p. 142) apud Ikeda e Veludo-de-Oliveira (2006) afirma que "valor para o cliente é a preferência e avaliação de um cliente relativa a atributos de produto, desempenho desses atributos e consequências advindas do uso que facilitam (ou dificultam), para esse cliente, a tarefa de atingir seus objetivos e propósitos em situações de uso".

Esse conceito abrange a compreensão de valores almejados e conseguidos e aponta que o valor para o cliente surge das percepções aprendidas, de preferências e avaliações. Salientam, ainda, o valor diante de situações de uso do produto, vinculando atributos de produtos e seu desempenho às conseqüências e aos objetivos pretendidos com seu uso (IKEDA E VELUDO-DE-OLIVEIRA, 2006).

Kotler e Keller (2006) diferenciam identidade, que é o modo como a empresa busca identificar-se ou posicionar a si mesma ou a seu produto; de imagem, que é a o modo como os consumidores percebem a empresa ou seus produtos.

Segundo os autores, para que a identidade seja eficaz precisa de: i) estabelecer a personalidade do produto e a proposta de valor; ii) comunicar esta personalidade de forma diferenciada; iii) transmitir ao mercado consumidor poder emocional além da imagem mental.

Os atributos entendidos como essência da marca devem estar presentes em todos seus produtos, processos e serviços, devendo ser percebidos nas ações da organização e de seus gestores com relação a todos seus públicos, como com a sociedade em geral (COLOMBO, 2005).

Consoante Las Casas (2008), as organizações, em razão do desenvolvimento de valor e a necessidade de uma relação mais próxima e duradoura com o cliente, têm desenvolvido ferramentas mais sofisticadas de administração, como marketing de relacionamento, marketing com banco de dados, CRM - Gerenciamento da relação com o cliente, Fidelização e Marketing um a um.

Telford e Masson (2005) apud Voss et al (2007) apontam que a qualidade percebida do serviço educativo depende das expectativas dos alunos e 
valores. Eles citam diversos estudos que indicam o impacto positivo das expectativas e dos valores variáveis, tais como a participação dos alunos (Claycomb et al., 2001), clareza de papéis, e motivação para participar no processo (LengnickHall et al., 2000; Rodie e Kleine, , 2000).

Zeithaml et al. (1993), por sua vez, distinguem três tipos de expectativas de serviço: o desejado, o adequado, e o previsto. Os clientes têm um nível de serviço desejado e eles esperam receber o que acreditam que compreendem possa ser realizado e que deva ser realizado. Os clientes também têm um nível mínimo de serviço aceitável e eles percebem que o serviço nem sempre alcança os níveis desejados, sendo este o nível de serviço adequado. Entre estes dois níveis de serviço há uma zona de tolerância que os clientes estão dispostos a aceitar. Por fim, os clientes têm um nível previsível de serviço, que é o nível de serviço que eles acreditam que a empresa irá executar.

\subsection{Marketing Educacional}

Para Hayes (2006), ao desenvolver sua pesquisa nos Estados Unidos, percebeu-se que o marketing do ensino superior surgiu em meados da década de 1980 como um ramo da área de marketing da área da saúde, vez que estudiosos como Philip Kotler, Roberta Clarke, Karen Fox, James Burns detectaram as seguintes tendências no mercado de ensino superior que se espelharam na área de saúde:

- As mudanças demográficas em 1980 causaram um excedente de camas de hospital que levou ao fechamento e fusões de hospitais. Da mesma forma, as tendências demográficas mostraram que a idade potencial de dezoito anos de idade para se inserir no mercado de educação superior estava em forte declínio. Em particular, a diminuição da população branca, estudantes de classe média à média superior foi motivo de preocupação. Este fator forçaria uma mudança para novos mercados potenciais/fusões e fechamentos no futuro.

- Aumento dos custos operacionais, em parte alimentados pelo custo de aquisição e implementação da tecnologia, impactou as instituições de saúde. Embora os dispositivos novos e melhores diagnósticos fossem introduzidos no mercado, que eram caros para adquirir, manter e substituir. Da mesma forma, a era do computador afetou os custos e os mecanismos de educação superior. 
- A resistência dentro da própria organização foi talvez o maior desafio para marketing da área saúde. Médicos e prestadores de cuidados de saúde tendem a não aceitar o marketing como um instrumento adequado para o setor, equiparando assim com marketing a publicidade e a venda pessoal que degradou a profissão. As mesmas percepções existiram no ensino superior entre professores e administradores, que temiam que o marketing afetaria a natureza e a integridade da academia. Com tempo, o marketing tornou-se uma ferramenta valiosa para garantir a sobrevivência e sucesso de muitas instituições de saúde. Todos os anos, cresceu a aceitação e o campo se expandiu. Do mesmo modo, muitos estudiosos estavam confiantes que este mesmo padrão ocorreria no ensino superior (Blackburn, 1980; Dolence, 1993; Ferrari, e Lauer, 2000; Hayes, 1991; Kotler e Clarke, 1986; Kotler e Fox, 1995 Topor;, , 1997). (HAYES, 2006, pp. 1 e 2)

Assim, o Marketing educacional é o esforço de posicionamento/comunicação praticado por instituições de ensino junto ao seu público alvo de seus produtos e serviços, bem como a determinados grupos sociais ou mesmo à própria sociedade (LAS CASAS, 2008).

Para Colombo (2005), o marketing educacional necessita de um tratamento especial de todas as suas dimensões: como cultura, como estratégia e como tática.

Manes (1997) apud Colombo (2005) define marketing de serviços educacionais como:

O processo de pesquisa de necessidades sociais o qual visa desenvolver e elaborar programas educativos que as satisfaçam e proporcionem um crescimento integral do indivíduo por meio do desenvolvimento de serviços de educação que criem valor, disponíveis em tempo e lugar e promovidos de forma ética para proporcionar o bem-estar de organizações e indivíduos (MANES, 1997, p. $17^{6}$, apud COLOMBO, 2005, p. 26).

Atualmente, no Brasil, há uma instabilidade política na área educacional, pois existe uma forte regulamentação e políticas que mudam rapidamente, dificultando um planejamento adequado. Dessa forma, há diferentes tipos de IES (Instituição de Educação Superior), assim como vários formatos de ensino, que variam em duração, formação, tecnologias e modos de entrega (COLOMBO, 2005).

\footnotetext{
${ }^{6}$ MANES, Juan Marques. Marketing para instituiciones educativas. Barcelona: Ediciones Granica, 1997.
} 
Dessa forma, conforme aponta Las Casas (2008), a educação passa por transformações profundas sendo que os efeitos podem ser verificados pela ampliação da concorrência no setor, o que acaba gerando o excesso de vagas em variados cursos.

Para se estabelecer e se manter neste mercado competitivo, as IES devem definir uma postura mais profissional e adequada a esta nova realidade, usando o marketing como instrumento transformador (LAS CASAS, 2008).

Cobra e Braga (2004) afirmam que, equivocamente, a maioria das IES orienta-se para o produto e não para o cliente, vez que focam no desenvolvimento de cursos com corpo docente qualificado e com currículo reforçado, sem se preocupar com o que efetivamente o aluno deseja.

Conforme comenta Las Casas (2008) o marketing direcionam as instituições de ensino superior na busca de mercados-alvo mais atraentes e específicos, de acordo com a oferta de cursos/serviços oferecidos, com a orientação e coordenação de todos seus esforços mercadológicos.

O autor aponta como obstáculos para as instituições:

(...) o limite da demanda com poder aquisitivo; excesso de instituições e vagas; falta de financiamento; falta de professores titulados e qualificados; e superposição de IES com as mesmas características (LAS CASAS, 2008, p. 95).

Segundo Fornari et al (2009), há um consenso no setor da importância do planejamento estratégico das IES, tendo em vista que com as bruscas mudanças no mercado de educação superior, é inconcebível uma IES sem um planejamento estratégico, mesmo que mínimo.

Assim, para os autores, o planejamento de marketing é primordial para qualquer IES, vez que poderá criar as condições para que a instituição de ensino superior possa decidir diante do ambiente externo, identificando suas oportunidade e ameaças e otimizando as vantagens competitivas frente aos concorrentes.

Deve ser desenvolvido um plano para cada uma das seis áreas principais de ação de marketing em uma IES, que são: plano de marketing da marca, plano de marketing por categoria de produto ou serviço; plano para novos 
produtos; plano por segmento de mercado; plano por mercado geográfico; e plano por cliente (FORNARI ET AL., 2009).

Ikeda e Veludo-de-Oliveira (2006) apontam que um aluno ao se inscrever em um curso, não busca somente aulas, o acesso à biblioteca ou o diploma; mas também almeja instrução, desenvolvimento pessoal, reputação, possibilidades de ascensão social e de carreira.

Da mesma forma, para as autoras, o desejo do estudante por ter acesso a um curso com infraestrutura de ponta é enfraquecido caso os recursos técnicos, computacionais e audiovisuais disponíveis não proporcionem e estimulem seu aprendizado, pois as características dos produtos somente têm utilidade ou sentido quando servem a alguma necessidade fundamental ou a valores pessoais. Assim, identificar relações entre as características do produto e os valores pessoais é fundamental para prover programas e produtos com capacidade de criar valor aos públicos da organização, o que é válido também para as instituições educacionais. 


\section{MÉTODOS E TÉCNICAS DE PESQUISA}

Ao pensar o método, deve-se ter em mente que não apenas se está falando de uma descrição de procedimentos para um resultado. Antes, deve imaginar por qual motivo se escolheu aquele caminho. Todo método pode ser válido, desde que sua sistemática consiga refletir cientificamente sua linha de pensamento e os dados coletados para análise. Trujillo (apud Marconi e Lakatos, 2004, p. 44) tenta definir da seguinte forma:

Método é a forma de proceder ao longo de um caminho. Na ciência, os métodos constituem os instrumentos básicos que ordenam de início o pensamento em sistemas, traçam de modo ordenado a forma de proceder do cientista ao longo de um percurso para alcançar um objetivo.

Para tanto, trata-se de uma pesquisa aplicada, vez que busca gerar soluções potenciais para os problemas humanos, havendo uma preocupação teórica por tratar-se de um estudo na área de Marketing que investiga os fatores que explicam o comportamento do consumidor (ROESCH, 2007).

Para escolher a metodologia adequada para o trabalho científico, ou seja, o caminho a ser percorrido, faz-se necessária a compreensão científica da linha de pensamento adotada, com a definição dos aspectos essenciais deste procedimento, tais como as abordagens ontológica e epistemológica; a descrição do método a ser utilizado, como também os instrumentos de coleta de dados; escolha do público-alvo, como descrito a seguir.

\subsection{Tipo e descrição geral da pesquisa}

\subsubsection{Abordagens Ontológica e Epistemológica}

\subsubsection{Considerações ontológicas}

Questões da ontologia social preocupam-se com a natureza das entidades sociais. O ponto central desta orientação é a questão de saber se as 
entidades sociais podem e devem ser consideradas entidades objetivas que têm uma realidade externa aos atores sociais, ou se que elas podem e devem ser entendidas como construídas socialmente a partir as percepções e ações dos atores sociais. Estas posições são referidas, respectivamente, como objetivismo e construtivismo (BRYMAN, 2008).

O objetivismo é uma posição ontológica que afirma que os fenômenos sociais e seus significados têm uma existência que é independente dos atores sociais. Por sua vez, o construtivismo é uma posição ontológica que a afirma que os atores sociais e seus significados são realizados continuamente pelos atores sociais (BRYMAN, 2008).

Esta pesquisa adota uma abordagem ontológica objetivista, considerando, portanto, que Instituições (organizações e valores) agem como forças externas e constrangedoras de comportamentos; e culturas agem como forças constrangedoras de comportamento, porque as pessoas internalizam suas crenças e valores.

\subsubsection{Considerações epistemológicas}

Questão epistemológica diz respeito ao que é (ou deveria ser) considerado como conhecimento aceitável em uma disciplina. O ponto central neste contexto é a questão de saber se o mundo social pode e deve ser estudado, de acordo com os princípios, procedimentos e ethos, como as ciências naturais. Esta posição que afirma a importância da imitação das ciências naturais é invariavelmente associada com uma abordagem epistemológica conhecida como positivismo (BRYMAN, 2008).

Por outro lado, o interpretativismo é uma posição epistemológica que contrasta com o objetivismo, pois subsume à visão dos autores que têm sido críticos da aplicação do modelo científico para estudar o mundo social.

Este termo, segundo Bryman (2008, p. 16):

... geralmente denota uma alternativa ao positivismo ortodoxo que dominou por décadas. Ele se baseia na visão de que é necessária uma estratégia que respeite as diferenças entre as pessoas e os 
objetos da ciência natural e, portanto, exige que o cientista social entenda o significado subjetivo da ação social (BRYMAN, 2008, P.16).

Assim, esta pesquisa adota uma perspectiva epistemológica positivista, vez que considera que apenas o conhecimento confirmado pelos sentidos pode ser considerado como genuíno; o propósito da teoria é gerar hipóteses a serem testadas; o conhecimento advém da coleta de fatos que pavimentam a base para o desenvolvimento de leis; e a ciência deve ser conduzida de forma "value free"7 .

\subsubsection{Método}

Como evidenciado, a pesquisa busca sustentação na Teoria Positiva, tendo em vista que se baseia na tentativa de explicação do que está acontecendo no mundo real e de fazer sentido sobre como as coisas acontecem.

Segundo Bryman (2008, p. 31), "método de pesquisa é simplesmente a técnica para coleta de dados, que pode envolver um instrumento específico", sendo que para este estudo adota-se o método quantitativo.

O método estatístico é caracterizado como uma descrição quantitativa de uma dada realidade. Sua organização visa delimitar em classes ou categorias as características comuns e/ou variáveis de um dado (GIL, 2006). Dessa forma, a possibilidade de generalização e manipulação das relações estatísticas pode fornecer uma metodologia capaz de ser descrita e analisável. A metodologia estatística, então, serviu como pesquisa de coleta de dados e sistematização para a interpretação dos dados.

Para tanto, é necessário estabelecer critérios de validade, confiabilidade e significância dos dados coletados e analisados.

Em relação aos critérios de confiabilidade, refere-se à consistência ou estabilidade dos dados analisados. Uma das medidas que pode ser usada mais facilmente é a do desvio-padrão, em que os valores mais altos indicam um menor grau de confiabilidade.

\footnotetext{
${ }^{7}$ Livre de valores
} 
Quanto à validade, que seria o grau em que uma variável pode realmente ser medida pelo instrumento usado. Ela pode ser de cinco tipos: aparente, de critério, de constructo, de conteúdo e total. A aparente é a mais simples, que considera apenas a definição teórica de uma variável. A de critério é a validade da variável em relação a um critério externo já definido. A validade de conteúdo mede o grau em que um instrumento evidencia um domínio específico do que se pretende medir. A de constructo é aquela que mede o grau em que um instrumento de medidas se relaciona consistentemente com outras medições semelhantes, derivada da mesma teoria e de conceitos do que está sendo medido, e a total seria a soma das medidas de validade de constructo, de critério e de conteúdo (BRYMAN, 2008).

O grau de significância é aquele que indica se o resultado é válido estatisticamente. Em ciências sociais, o valor mais usado é de um valor de $\alpha=5 \%$.

\subsection{Caracterização da organização, setor ou área}

\subsubsection{Nome da Organização}

\section{ESCOLA SUPERIOR PROFESSOR PAULO MARTINS - ESPAM}

\subsubsection{Registro e situação legal:}

A Escola Superior Professor Paulo Martins - ESPAM, funciona na Quadra 04 Área Reservada 01 - Sobradinho/DF, é um estabelecimento isolado particular de ensino superior, criado e mantido pela Associação União de Ensino Superior Paulo Martins, para ministrar cursos em nível superior.

A Associação União de Ensino Superior Paulo Martins, fundada em 02.01.2000, é uma sociedade civil, sem fins lucrativos, e está protocolada e registrada em Microfilme sob $n^{\circ}$ 01922, no Cartório do $2^{\circ}$ Ofício de Notas, Registro Civil, Protesto de Títulos, Registro de Pessoas Jurídicas e de Títulos e Documentos de Sobradinho/DF, sendo inscrita no CNPJ sob número 03.619.353/0001-62, tem 
dependência administrativa particular, sua personalidade jurídica é sociedade civil de direito privado e tem por finalidade:

- Criar e manter estabelecimentos de ensino, de todos os graus e níveis, com estrita observância da legislação em vigor, para atender as necessidades sociais, técnicas e culturais da comunidade de Brasília e da região onde se situa;

- Participar da formação educacional, sistemática e assistemática da comunidade, oferecendo-lhe cursos e serviços que atendam efetivamente suas necessidades e aspirações;

- $\quad$ Promover sua ação educativa, cultural, desportiva e social, com vistas à peculiar realidade geoeconômica da região onde atua; e

- Pugnar por uma educação humanística, integral e permanente como proposta de pleno desenvolvimento das potencialidades humanas de forma harmônica com a ecologia e o meio ambiente.

\subsubsection{Ano de fundação}

A Escola Superior Professor Paulo Martins foi credenciada pelo Ministério da Educação, por meio da Portaria MEC n 438, de 9 de março de 2001.

A faculdade iniciou suas atividades acadêmicas no $2^{\circ}$ semestre letivo do ano de 2001.

\subsubsection{Número de sócios}

A entidade mantenedora da Escola Superior Professor Paulo Martins possui 8 sócio-fundadores, sendo que a gestão da organização é realizada por meio da uma Diretoria composta por: Presidente, Tesoureiro e Diretor Administrativo. 


\subsubsection{Campo de atuação}

Sua área de atuação abrange ensino, pesquisa e extensão, incluindose cursos de pós-graduação próprios ou em parcerias com outras instituições de ensino superior autorizadas.

\subsection{6 Área de abrangência}

A oferta de cursos superiores não se limita a uma área geográfica específica.

Entretanto, pela sua localização, a faculdade ESPAM atende os moradores da região norte do Distrito Federal, em especial as cidades de Sobradinho e Planaltina/DF, além abranger também a região do entorno, especificamente as cidades de Formosa/GO e Planaltina/GO.

\subsubsection{Histórico da organização}

A ESPAM foi criada em 2001, em Sobradinho/DF, mantida pela Associação União de Ensino Superior Paulo Martins, para ministrar cursos de nível superior, que em muito vem contribuindo para o desenvolvimento desta cidade.

Fruto de um projeto de seus idealizadores, preocupados com a implantação de uma IES em Sobradinho/DF, que formasse profissionais altamente qualificados nas diversas áreas do conhecimento, além de proporcionar o enriquecimento cultural da cidade.

Em 2006, foi criado o campus da ESPAM em Planaltina/DF, o que colaborou para o desenvolvimento daquela cidade e ampliou a oferta de ensino superior na região. 
A criação da Escola Superior Professor Paulo Martins buscou interagir juntamente com outros setores governamentais e privados no sentido de atender a uma demanda cada vez mais crescente da população por Ensino Superior.

A proposta pedagógica da ESPAM remete a uma nova visão da Educação com conteúdos curriculares flexíveis que desenvolvam competências e habilidades capazes de mudar substancialmente formas de conviver, exercer a cidadania e de organizar o trabalho.

\subsubsection{Estrutura organizacional e administrativa}

O Regimento Interno da faculdade, aprovado pelo órgão competente, apresenta a seguinte estrutura organizacional:

\section{ÒRGÃOS}

CONSELHO SUPERIOR - órgão superior de natureza deliberativa em matéria administrativa, econômico-financeira e de planejamento.

CONSELHO ACADÊMICO - órgão de natureza deliberativa, normativa e consultiva, é destinado a orientar, acompanhar e avaliar as atividades didático-científicas da faculdade.

DIRETORIA GERAL - exercida pelo Diretor, é órgão executivo superior, competindoIhe coordenar, superintender e fiscalizar as atividades da faculdade.

COORDENADORIA DE CURSO - é à base das funções de ensino, pesquisa e extensão da faculdade.

\section{ÓRGÃOS DE APOIO}

SECRETARIA DE REGISTROS ACADÊMICOS - o órgão central de desempenho e Registros Acadêmicos competindo ao Secretário Geral de Registros Acadêmicos ASSESSORIA EDITORIAL - órgão de assessoramento da Diretoria responsável pela publicação da produção acadêmica vinculada ao ensino, à pesquisa, a extensão e à gestão da faculdade. 
CENTRO DE PESQUISA E PLANEJAMENTO - como órgão encarregado do planejamento e da pesquisa, devendo assegurar o funcionamento contínuo de suas atividades e estender à comunidade seus serviços.

\subsubsection{Cursos oferecidos pela ESPAM:}

Sobradinho/DF

Matutino - Sistemas de Informação, Direito e História

Noturno - Pedagogia, Administração, Letras e Direito

Planaltina/DF

Noturno - Ciências Contábeis e Matemática

\subsection{População e amostra ou participantes do estudo}

O público alvo foi composto pelos alunos da Escola Superior Professor Paulo Martins - ESPAM, localizada na cidade satélite de Sobradinho, Distrito Federal, matriculados no segundo semestre de 2010, nos variados períodos de todos os cursos oferecidos pela IES, totalizando aproximadamente 1.800 estudantes regularmente matriculados.

Para definir a amostra da população a ser pesquisada, optou-se pela aplicação da fórmula definida por Barbetta (2006):

Para o cálculo da aproximação, utiliza-se a margem de erro de 5\%.

$\mathrm{N}_{0}=1 / \mathrm{e}^{2}$

Onde:

$\mathbf{N}_{0}$ é a aproximação.

e é a margem de erro.

$\mathbf{N}_{0}=1 /(0,05)^{2}$ 
$\mathbf{N}_{0}=1 / 0,0025$

$\mathrm{N}_{0}=400$

Para o cálculo do número de questionários a partir da população identificada:

$\mathrm{N}=\left(\mathrm{IN} \cdot \mathrm{N}_{0}\right) /\left(\mathrm{IN}+\mathrm{N}_{0}\right)$

Onde:

$\mathbf{N}$ é o número total de questionários a serem aplicados

IN é a população

$\mathbf{N}_{0}$ é a aproximação

$\mathbf{N}=(1800.400) /(1800+400)$

$\mathbf{N}=720.000 / 2200$

$\mathbf{N}=327,27$

Portanto, foram aplicados 327 questionários entre os alunos regularmente matriculados na Faculdade ESPAM, durante o mês de setembro de 2010.

\subsection{Caracterização dos instrumentos de pesquisa}

Nesta pesquisa, foram utilizados questionários, além da revisão da literatura e também foi utilizada a análise documental que permitiu complementar informações obtidas por outras técnicas.

Gil (2006) afirma que questionário é o instrumento de coleta de dados constituído por uma série ordenada de perguntas, que devem ser respondidas por escrito e preferencialmente na presença do entrevistador.

A construção do questionário consistiu em traduzir os objetivos da pesquisa em perguntas claras e objetivas.

Na elaboração dos questionários foram formuladas questões abertas e fechadas e foram pré-testados com uma amostra de 15 respondentes. 
Para a coleta dos dados, por meio do questionário, e já visando seu estudo interpretativo, houve divisão das dimensões em categorias de análise, de acordo com os objetivos específicos deste trabalho, objetivando a sistematização dos dados, conforme descrição abaixo:

\begin{tabular}{|c|c|}
\hline DIMENSÃO & CATEGORIAS DE ANÁLISE \\
\hline 1. Perfil sócio-econômico da clientela & $\begin{array}{l}\text { - Perfil socioeconômico (idade, } \\
\text { escolaridade, sexo, renda familiar } \\
\text { entre outros) } \\
\text { - Perfil } \\
\text { (cargo/função, lotação, tempo de } \\
\text { trabalho entre outros) } \\
\text { - }\end{array}$ \\
\hline 2. Necessidades da clientela & $\begin{array}{l}\text { - } \text { Cursos desejados } \\
\text { - Estrutura física } \\
\text { - Serviços }\end{array}$ \\
\hline 3. Percepções da clientela & $\begin{array}{l}\text { - Percepções quanto à imagem da } \\
\text { faculdade. } \\
\text { - Percepções quanto aos valores } \\
\text { agregados pela faculdade. }\end{array}$ \\
\hline 4. Fatores de influência na escolha & $\begin{array}{ll}\text { - } & \text { Localização } \\
\text { - } & \text { Qualidade de ensino } \\
\text { - } & \text { Preço } \\
\text { - } & \text { Credibilidade }\end{array}$ \\
\hline 5. Motivos de rejeição & $\begin{array}{l}\text { - Falta de tradição } \\
\text { - Status pessoal }\end{array}$ \\
\hline
\end{tabular}

No decorrer da pesquisa, as categorias de análise foram desdobradas em indicadores o que facilitou a estruturação do trabalho e a análise dos dados coletados.

Foi usada a Escala Likert para resposta do questionário, sendo que o respondente escolheu uma das categorias abaixo que melhor expressou a sua opinião:

\begin{tabular}{|l|l|l|l|l|}
\hline \multicolumn{1}{|c|}{$\mathbf{1}$} & \multicolumn{1}{|c|}{$\mathbf{3}$} & \multicolumn{1}{c|}{$\mathbf{4}$} & \multicolumn{1}{c|}{$\mathbf{5}$} \\
\hline $\begin{array}{l}\text { Discordo } \\
\text { totalmente }\end{array}$ & $\begin{array}{l}\text { Discordo em } \\
\text { parte }\end{array}$ & $\begin{array}{l}\text { Não sei ou não } \\
\text { quero } \\
\text { responder }\end{array}$ & $\begin{array}{l}\text { Concordo em } \\
\text { parte }\end{array}$ & $\begin{array}{l}\text { Concordo } \\
\text { totalmente }\end{array}$ \\
\hline
\end{tabular}


O instrumento de pesquisa encontra-se em anexo a esta monografia.

\subsection{Procedimentos de coleta e de análise de dados}

O questionário foi pré-testado em 15 respondentes no dia 06.09.2010, sendo cronometrado o tempo médio de resposta, como também foi solicitado aos participantes que anotassem os pontos que tiveram dificuldade em responder ou interpretar.

Após a aplicação do pré-teste, houve a análise dos questionário aplicados, especialmente quanto aos possíveis itens que necessitassem de ajustes.

Percebeu-se, durante a análise, que foi necessário apenas corrigir um erro de digitação e alterar uma afirmativa para que o enunciado ficasse mais objetivo.

Na semana de 13 a 17.09 .2010 foram aplicados presencialmente os questionários, sendo distribuídos aleatoriamente nas turmas dos turnos Matutino e Noturnos, nos diversos cursos da faculdade.

O pesquisador, quando da entrega dos questionários em sala de aula, esclareceu que se tratava de uma pesquisa científica e que a resposta era facultativa, não se obrigando o respondente em devolver o instrumento preenchido.

Houve uma taxa de resposta de $79,8 \%$, o que corresponde a 261 questionários devolvidos.

Os dados foram digitalizados em planilha Excel, o que permitiu a análise estatística dos resultados, extraindo as médias de cada item analisado, como a aplicação de testes e análise regressiva, conforme apresentados no discussão dos resultados. 


\section{RESULTADOS E DISCUSSÃO}

Os resultados são apresentados a seguir, bem como a sua discussão com a interpretação por meio de tabelas e gráficos que representam o que foi evidenciado na pesquisa.

Para tanto, a interpretação dos resultados, com a devida ilação com a revisão da literatura, obedecerá aos tópicos levantados nos objetivos específicos da pesquisa, ou seja: perfil socioeconômico da clientela; necessidades da clientela por educação superior; percepção da clientela quanto aos valores e imagem da faculdade; deficiências da faculdade sob a ótica da clientela; e indicadores que influenciam a clientela na escolha por uma faculdade.

\subsection{Perfil socioeconômico}

A pesquisa foi realizada com alunos da Faculdade ESPAM em Sobradinho/DF, sendo apresentados por meio de gráficos, o perfil socioeconômico dos respondentes.

Com relação ao sexo dos respondentes, $2 \%$ não responderam a este item, $28 \%$ são do sexo masculino e $70 \%$, a maioria, do sexo feminino, conforme representado no Gráfico 1.

Gráfico 1 - Sexo

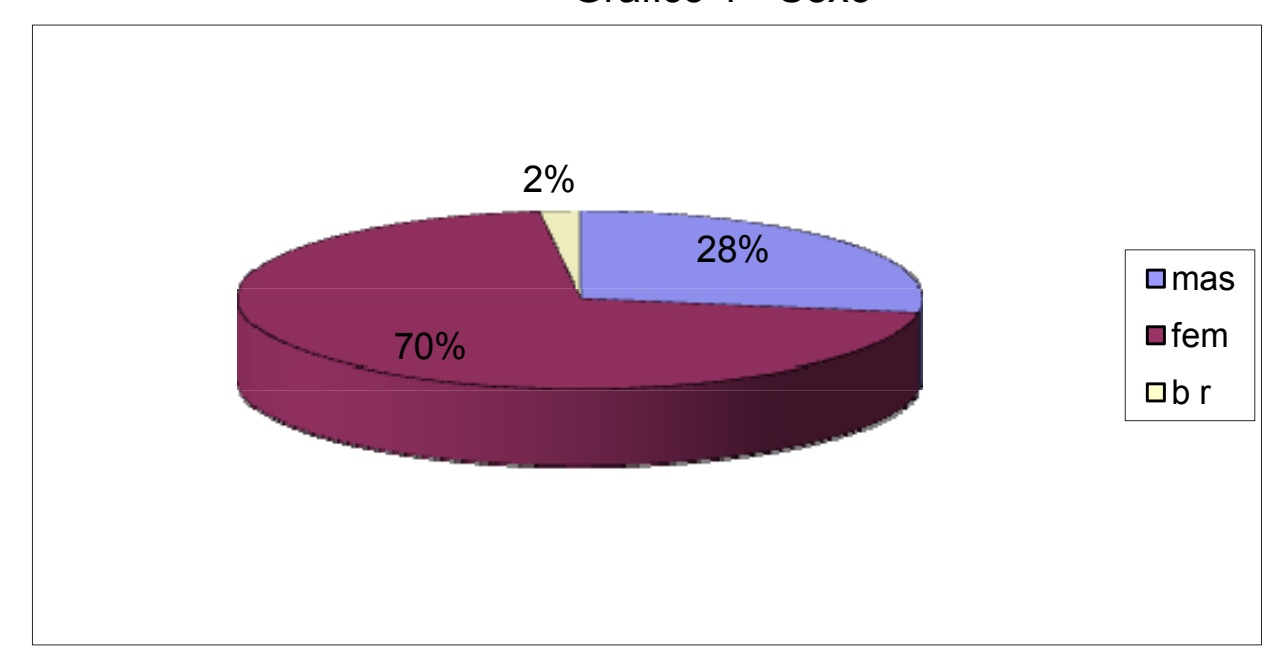


Os respondentes foram divididos em 5 classes de faixa etária, a saber: alunos com idade até 20 anos, alunos de 21 a 25 anos, de 26 a 30 anos, de 31 a 35 na os, de 36 a 40 anos e acima de 40 anos.

O Gráfico 2 demonstra a participação percentual de cada classe de faixa etária na composição da amostra.

Gráfico 2 - Faixa etária

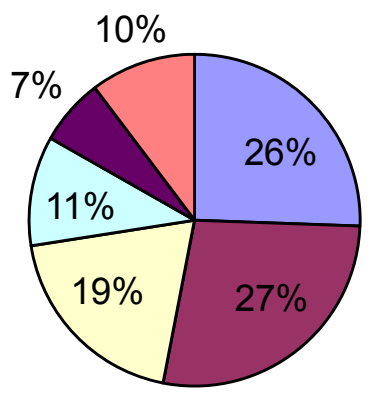

口Até 20 anos

口de 21 a 25

口de 26 a 30

口de 31 a 35

$\square$ de 36 a 40

口Acima 40 anos

Verifica-se uma maior participação na faixa etária compreendida entre 21 a 25 anos, com $28 \%$ dos respondentes, seguida da classe de até 20 anos, com $26 \%$, o que totaliza $54 \%$ dos alunos com idade até 25 anos. Esses dados evidenciam a maioria dos alunos da Faculdade ESPAM se encontra na faixa etária considerada jovem, o que é condizente com o perfil desejado para a Educação Superior, ou seja, alunos que são recém egressos do Ensino Médio.

Todavia, observa-se que $46 \%$ dos respondentes têm mais de 26 anos, sendo que $10 \%$ têm idade superior a 40 anos, o que demonstra que a faculdade pode oportunizar o acesso ao nível superior mesmo àquelas pessoas que se encontram em idade superior à faixa etária média dos estudantes de Educação Superior (até 25 anos).

Por sua vez, a relação de alunos que trabalham ou fazem estágios com os que não têm atividade remunerada é apresentada no Gráfico 3. 
Gráfico 3 - Atividade remunerada

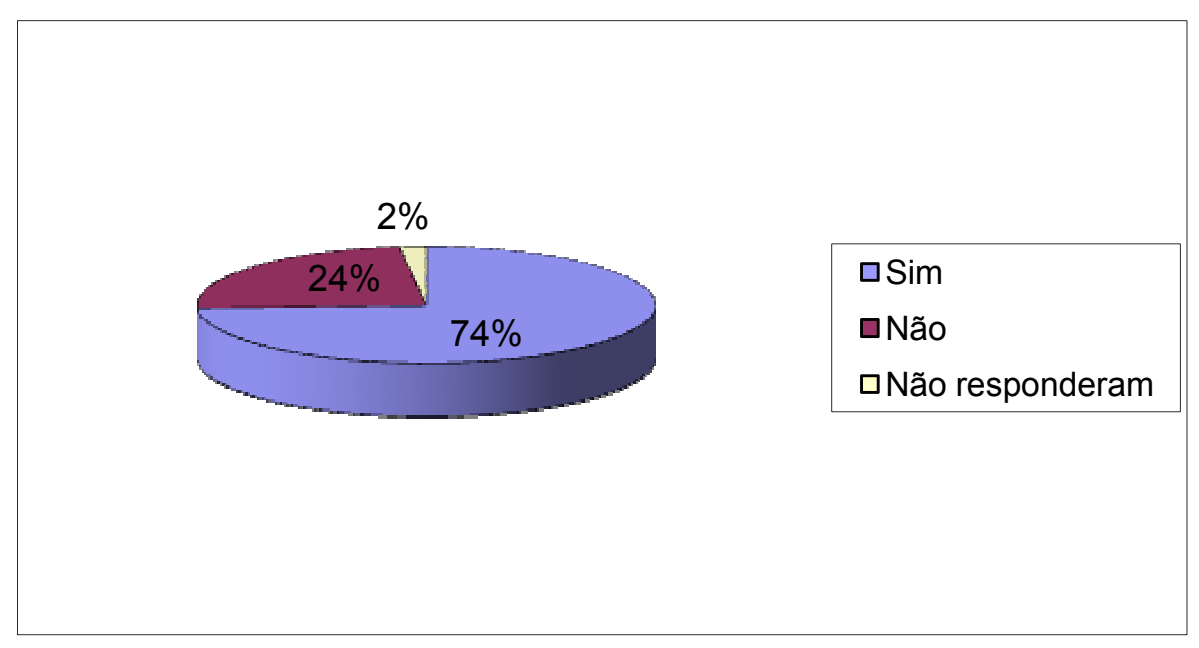

Percebe-se que $74 \%$ dos alunos têm atividade remunerada, $24 \%$ não tem e $2 \%$ não responderam este quesito, o que evidencia que o corpo discente da faculdade é composto basicamente por "trabalhadores-estudantes", ou seja, pessoas que já atuam no mercado de trabalho e buscam, por meio da Educação Superior, ascensão na carreira ou mesmo reposicionamento no mercado de trabalho com formação superior ou um segundo curso, como formação continuada.

A renda familiar informada pelos alunos está demonstrada no Gráfico 4, o que evidencia que boa parcela dos alunos tem renda de até $R \$ 1.000,00$, com $36 \%$ dos respondentes, seguida de $22 \%$ dos alunos com renda entre $\mathrm{R} \$ 1.001,00 \mathrm{e}$ $\mathrm{R} \$ 2.500,00$. Somando-se as duas classes, tem-se que $58 \%$ dos alunos têm renda de até $R \$ 2.500,00$. 


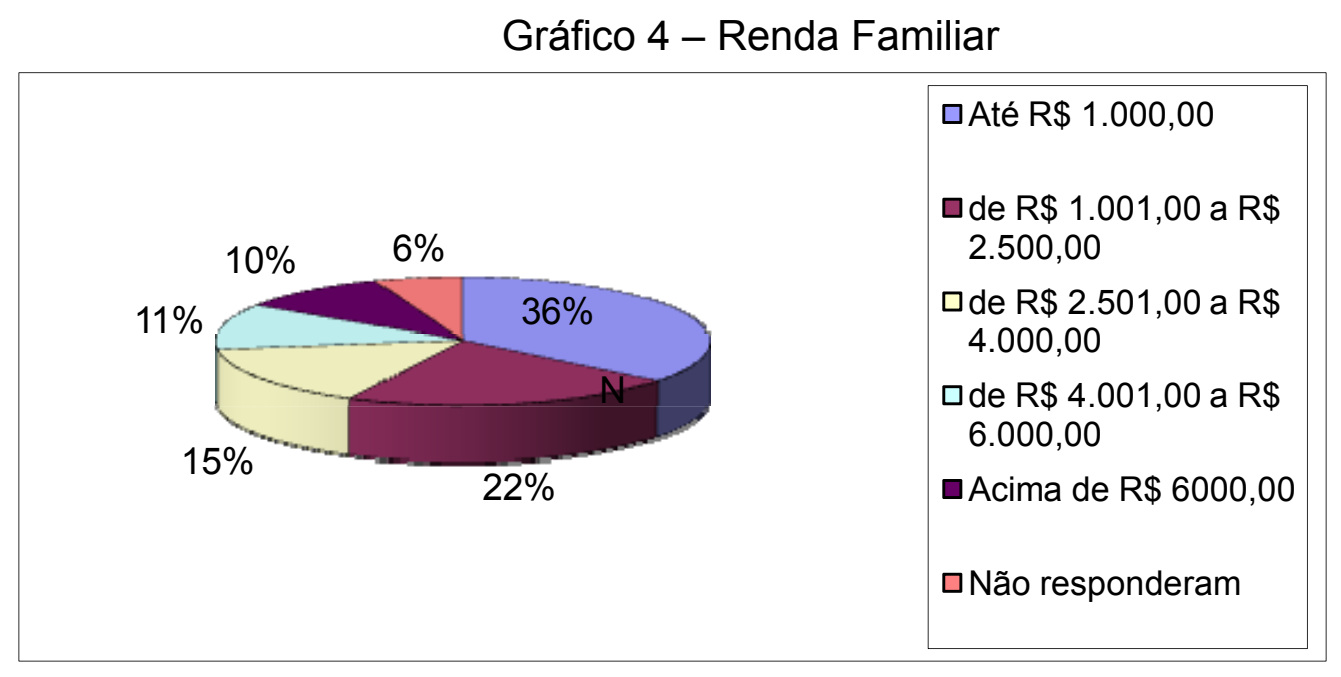

Este dado evidencia que a maioria dos alunos da faculdade situa-se na Classe C, caracterizando esta classe social como predominante nas IES particulares, especialmente de periferia, como é o caso da ESPAM. Sugere-se, portanto, a criação ou aumento de políticas de bolsas de estudo, descontos para pagamento em dia ou antecipado para aumentar a captação ou favorecer a fidelização de clientes.

Em relação como os alunos se mantém na IES, 58\% respondeu que custeiam seus estudos com recursos próprios e 18\% necessitam de ajuda de seus pais. Estas respostas podem ser consideradas como conflitantes com a resposta sobre a renda dos mesmos, pois 36\% informaram que têm renda familiar de até $\mathrm{R} \$$ $1.000,00$, valor relativamente baixo para manter o aluno na faculdade e ainda ter consumo satisfatório. Todavia, apenas $18 \%$ dos respondentes informaram necessitar de ajuda dos pais.

Entretanto, por outro lado, fica evidente que, de fato, a clientela é formada por alunos que são trabalhadores, que custeiam a sua própria formação e que está inserida no mercado de trabalho, a partir da faixa etária relativamente baixa, o que é maioria entre os respondentes. 
Gráfico 5 - Forma de custeio dos estudos

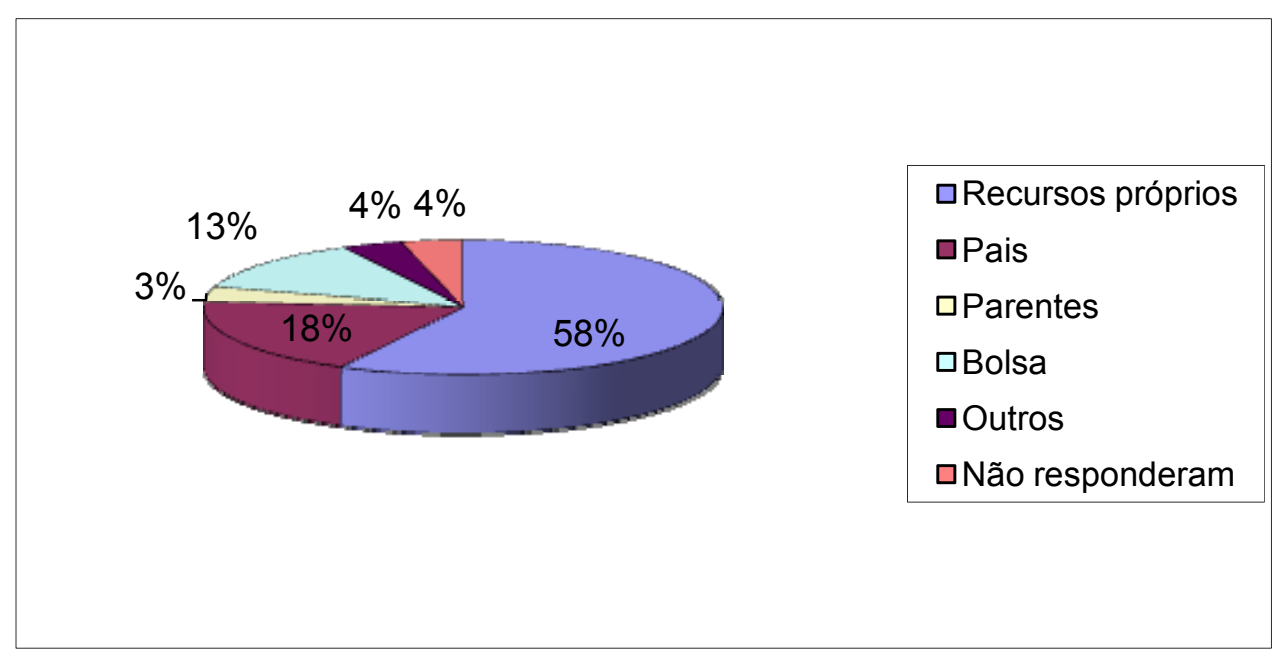

Destaca-se, ainda, que $13 \%$ dos respondentes possuem algum tipo de apoio para manutenção dos estudos por meio de bolsa de estudos, da própria faculdade, como também do Programa Bolsa Universidade do Governo do Distrito Federal, PROUNI e outras.

O estado civil dos respondentes está representado no Gráfico 6.

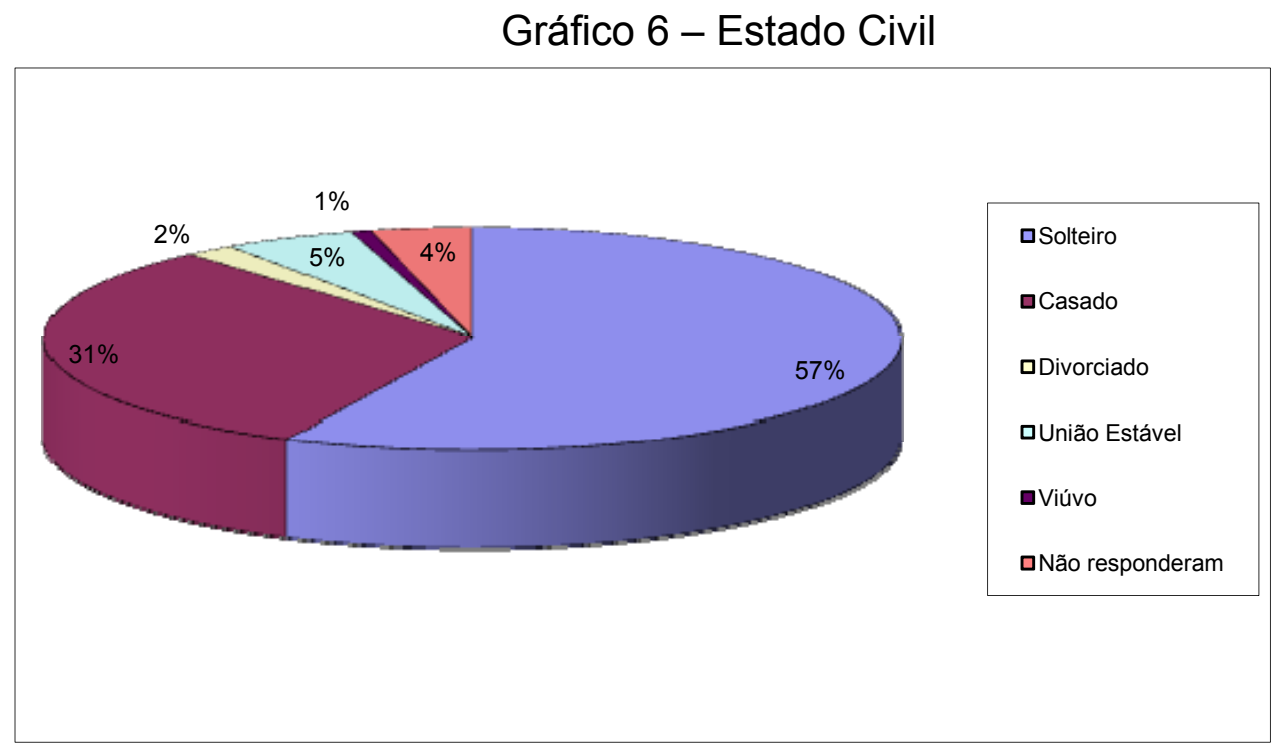


Observa-se $57 \%$ dos respondentes são solteiros e $31 \%$ são casados. Assim, infere-se que mesmo sendo uma população com renda relativamente baixa, o fato de a maioria ser solteira demonstra que não tem maiores compromissos financeiros familiares, permitindo a sua manutenção na faculdade. Quanto o local de moradia da clientela, o Gráfico 7 apresenta a distribuição dos respondentes por localidade.

Gráfico 7 - Local de moradia dos alunos.

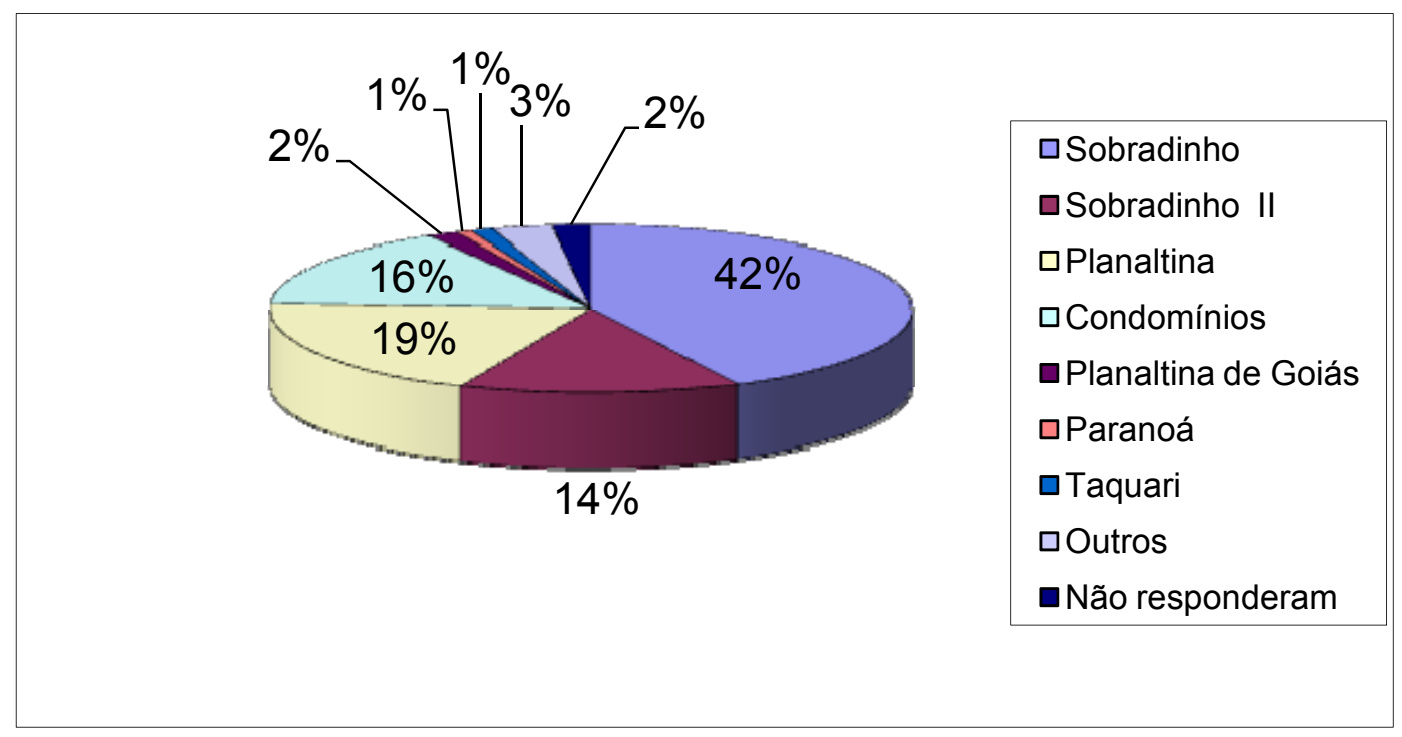

Segundo este gráfico os alunos da Faculdade ESPAM reside em diversas localidades, principalmente, em ordem de percentual, Sobradinho (42\%), onde está localizada a IES, Planaltina (19\%), onde a IES mantém o Curso de Ciências Contábeis, Sobradinho II (14\%) e nos Condomínios (16\%), que são áreas próximas de Sobradinho, com população em situação econômica um pouco maior do que o publico das outras localidades, mas cujos jovens podem preferir estudar em faculdades situadas na área central de Brasília.

Fica evidenciado, assim, que há um potencial de crescimento da faculdade junto a esta população, com o desenvolvimento de ações de marketing educacional que consiga atingir este público. 


\subsection{Necessidades da clientela por educação superior}

Ao serem indagados sobre a necessidade por educação superior e os motivos que levaram à escolha da Faculdade ESPAM, os respondentes optaram entre os valores de 1 a 5 , sendo que o 1 representava maior nível de discordância da afirmativa e o 5 o maior nível de concordância.

O Quadro 1 representa as médias de cada indicador, o que facilita a interpretação como tendência dos respondentes em concordar ou discordar das afirmativas.

Quadro 1 - Média dos indicadores de necessidades da clientela

\begin{tabular}{|l|c|}
\hline \multicolumn{1}{|c|}{ INDICADOR } & MÉDIA \\
\hline Escolhi a Faculdade Espam por falta de opção. & 2,37 \\
\hline Escolhi a Faculdade Espam por ter o curso que eu desejava. & 3,79 \\
\hline $\begin{array}{l}\text { Tenho amigos, conhecidos e parentes que não estudam na Faculdade } \\
\text { Espam por não ter o curso que desejam. }\end{array}$ & 3,30 \\
\hline A Faculdade Espam precisa divulgar melhor os seus cursos. & 4,14 \\
\hline $\begin{array}{l}\text { Sinto-me satisfeito com os serviços de atendimento administrativo ao } \\
\text { aluno (Secretaria, Tesouraria) prestados pela Faculdade Espam. }\end{array}$ & 2,90 \\
\hline A Faculdade Espam precisa melhorar o seu atendimento administrativo. & 3,60 \\
\hline $\begin{array}{l}\text { O curso que frequento tem atendido às minhas expectativas relacionadas } \\
\text { à qualidade do ensino. }\end{array}$ & 3,68 \\
\hline O curso tem me preparado para o mercado de trabalho. & 3,61 \\
\hline $\begin{array}{l}\text { O Corpo docente (equipe de professores) demonstra preparação para o } \\
\text { cargo. } \\
\text { minhas possibilidades financeiras. }\end{array}$ & 3,98 \\
\hline Eu mesmo (a) custeio os meus estudos. & 3,28 \\
\hline São meus pais ou parentes que custeiam os meus estudos. & 2,04 \\
\hline
\end{tabular}


O Quadro 1 permite a interpretação dos resultados desta categoria, além da ilação com a revisão bibliográfica sobre o tema, favorecendo o levantamento das necessidades de ações de marketing educacional específicos para o público interno, como proposta de endomarketing, bem como para a potencial clientela externa.

Fica evidente que a escolha pela Faculdade Espam se dá de forma consciente, pois a média de 2,37 (Intervalo de confiança entre 2,19 e 2,54) demonstra a discordância da clientela por ter sido motivada a estudar na ESPAM por falta de opção.

Além disso, a escolha também se deu em razão da oferta de cursos da ESPAM atender à necessidade da clientela, pois a média de 3,79 (Intervalo de confiança entre 3,62 e 3,96) evidencia a concordância que a escolha do curso ocorreu por vontade do cliente.

Como apontado por Magalhães e Sampaio (2007) o conjunto de ações do marketing fundamenta-se no marketing como filosofia dos negócios com foco no atendimento das necessidades do cliente, ou seja, seus desejos e vontades, o que demonstra que a Faculdade ESPAM atende ao desejo dos clientes pelos cursos oferecidos.

Entretanto, a média de 3,30 (Intervalo de confiança entre 3,10 e 3,50) na afirmativa sobre parentes ou amigos que não estudam na ESPAM por não ter o curso desejado demonstra que não se pode comprovar percepção do público alvo sobre este fato, pois há uma tendência para não opinar ou não querer responder.

Por outro lado, os respondem concordam que a Faculdade ESPAM precisa divulgar melhor os seus cursos (Média de 4,14), o que demonstra a sua percepção de que não há um marketing eficiente neste sentido.

Como afirmam Kotler e Keller (2006), administração de marketing deve ser a arte a ciência da escolha de mercados-alvos e da captação, manutenção e fidelização dos clientes por meio da criação, da entrega e da comunicação de um valor superior para o cliente. Ora, neste diapasão, a própria clientela percebe que há necessidade de criar, entregar e comunicar um valor superior, ou seja, divulgar melhor seus próprios cursos para a comunidade. 
Quanto aos serviços oferecidos pela ESPAM, especialmente na Secretaria e Tesouraria, a média de 2,90 (intervalo de confiança 2,72 a 3,07) aponta que os respondentes não sabem ou não querem responder sobre a satisfação plena com estes serviços o que pode evidenciar a necessidade de um atendimento melhor.

Quanto à necessidade de melhoria dos serviços administrativos da faculdade, a média de 3,60 (Intervalo de confiança entre 3,43 a 3,78) indica que os respondentes concordam que estes serviços precisam ser melhorados.

Como bem destacado por Loverlock E Wirtz (2006), o setor de serviços muda bruscamente, afetando diretamente o modo de vida das pessoas, vez que novos serviços são lançados de forma contínua, na busca da satisfação das necessidades existentes e outras que surgem constantemente. Assim, fica evidente que a clientela da IES reclama por melhoria contínua nos serviços administrativos.

Sobre o curso que o respondente está matriculado, há uma tendência para concordância de satisfação tanto para das expectativas quanto à qualidade de ensino, com média de 3,68 (Intervalo de confiança entre 3,54 a 3,83) como também para a preparação para o mercado de trabalho, média de 3,61 (Intervalo de confiança entre 3,46 a 3,75$)$.

Todavia, há que se ressaltar que estes indicadores apenas apontam esta tendência, vez que as médias se aproximam de 4, mas demonstra que há uma boa margem de crescimento nestes dois aspectos: qualidade de ensino e preparação para o mercado de trabalho.

Especialmente, a prestação de serviços educacionais, como afirmam Etzel et al (2001) são atividades intangíveis que buscam satisfazer um desejo do cliente. Assim, a oferta de curso superior por ter uma característica bem forte de intangibilidade pode gerar alguma dificuldade no cliente em identificar de forma clara e objetiva a sua aplicabilidade imediata.

Por sua vez, há o reconhecimento de que o corpo docente é um diferencial competitivo da faculdade, com média de 3,98 (Intervalo de confiança entre 3,85 a 4,12), tendo em vista a concordância com a afirmação de que a equipe de professores está preparada para o desempenho das funções. 
Loverlock E Wirtz (2006) apontam que elementos intangíveis dominam a criação de valor; clientes podem ser envolvidos no processo de produção (o que é o caso peculiar da educação superior; muitos serviços são difíceis de ser avaliados por clientes, o que corroboram as percepções observadas acima.

Além disso, estes autores apontam que a qualidade do serviço é frequentemente avaliada baseando-se nas interações dos clientes com o pessoal de linha de frente, sendo que devem ser dedicados esforços significativos ao recrutamento, treinamento e motivação dos colaboradores, devendo, portanto, ter uma atenção contínua na formação do corpo docente como manutenção deste diferencial.

Quanto aos preços praticados pela faculdade há uma tendência para não opinião ou não querer responder, com média de 3,28 (Intervalo de confiança entre 3,10 e 3,46), o que dificulta uma interpretação adequada da política de preços adotada pela IES.

Por fim, como apontado no perfil socioeconômico da clientela, há concordância, com média de 4,04 (intervalo de confiança entre 3,86 a 4,26) que o próprio aluno custeia seus estudos e discordância quanto à manutenção na faculdade às custas dos pais e/ou outros parentes, média de 2,04 (Intervalo de confiança entre 1,84 a 2,23), ou seja, o próprio aluno se mantém na faculdade sem apoio de pais ou parentes.

\subsection{Percepção da clientela quanto aos valores e imagem da faculdade}

O Quadro 2 representa as médias de cada indicador, o que facilita a interpretação como tendência dos respondentes em concordar ou discordar das afirmativas relacionadas à percepção da clientela quanto à imagem e valores da faculdade. 
Quadro 2 - Média da percepção quanto à imagem e valores

\begin{tabular}{|l|c|}
\hline \multicolumn{1}{|c|}{ INDICADOR } & MÉDIA \\
\hline A Faculdade Espam desperta credibilidade. & 3,60 \\
\hline A Faculdade Espam mantém uma postura de seriedade. & 3,86 \\
\hline A Faculdade Espam possui uma imagem de instituição de qualidade. & 3,69 \\
\hline Sinto orgulho de estudar na Faculdade Espam. & 3,53 \\
\hline Considero a Espam a melhor faculdade da cidade. & 3,78 \\
\hline Percebo que a Faculdade Espam demonstra compromisso com o aluno. & 3,46 \\
\hline A Faculdade Espam tem o respeito da comunidade. & 3,64 \\
\hline Indico a Faculdade Espam para amigos, conhecidos e parentes. & 3,85 \\
\hline
\end{tabular}

O Quadro 2 demonstra a tendência de concordância com a criação de imagem positiva da faculdade, assim como com a percepção de valores.

A Média de 3,60 (Intervalo de confiança entre 3,45 a 3,75) aponta uma certa indefinição sobre a percepção da credibilidade da faculdade com ligeira tendência à concordância.

Todavia, a clientela percebe de forma mais nítida a seriedade da instituição, pois há concordância com a afirmativa, média de 3,86 (Intervalo de confiança entre 3,72 a 3,99).

Da mesma forma, apenas há um tendência em reconhecer a ESPAM com uma imagem positiva, com qualidade, vez que apresenta uma média de 3,69 (Intervalo de confiança entre 3,55 a 3,86).

Como apontado por Magalhães e Sampaio (2007), Al Ries e Jack Trout, em 1972, conceituaram a estratégia de posicionamento como a ocupação de um determinado espaço conceitual na mente dos consumidores com um elemento 
diferenciador de um produto ou serviço. Assim, fica evidente que há uma tendência de conceituação da credibilidade, seriedade e qualidade, mas não muito presente na mente da clientela de forma mais efetiva, não sendo ainda um diferenciador do serviço.

$\mathrm{Na}$ realidade, os indicadores desta categoria, imagem e valor, encontram-se em uma margem de indefinição do respondente como uma tendência concordância.

Sobre o orgulho em estudar na faculdade, há um posicionamento de proximidade com a concordância, com média de 3,53 (Intervalo de confiança entre 3,38 a 3,68), enquanto os respondentes consideram a ESPAM como a melhor faculdade da cidade, vez que houve concordância, com média de 3,78 (Intervalo de confiança entre 3,62 a 3,95).

Por outro lado, também fica evidente um posicionamento de concordância do respondente quanto demonstra a sua percepção quanto ao compromisso da faculdade com o aluno, com média de 3,46 (Intervalo de confiança entre 3.31 a 3.61$)$.

Na mesma linha, os respondentes se posicionam de forma concordante sobre o respeito que a faculdade possui junto à comunidade, com média de 3,64 (Intervalo de confiança entre 3,51 a 3,77).

Por sua vez, apontam com mais convicção, com média de 3,85 (Intervalo de confiança entre 3,70 a 4,00) que indicam a faculdade para parentes e amigos.

Como afirmam De Toni e Schuler (2007) as imagens como representações, impressões, convicções e redes de significados de um objeto armazenado na memória de forma holística, sendo construída de forma sistêmica, podendo ser configurada a partir de um sortimento de elementos funcionais, simbólicos, cognitivos e emocionais.

Para os autores, quanto mais importante um produto for para o indivíduo (envolvimento), maior tenderá a ser a rede de significados associada a ele. 
Dessa forma, fica evidente que a imagem e os valores da faculdade para os respondentes ainda se encontra em um processo de construção, vez que os indicadores desta categoria apontam para concordância do respondente.

\subsection{Deficiências da faculdade sob a ótica da clientela}

O Quadro 3 evidencia as médias de cada indicador, o que facilita a interpretação como tendência dos respondentes em concordar ou discordar das afirmativas relacionadas à percepção das deficiências da faculdade sob a ótica dos respondentes.

Quadro 3 - Média da percepção das deficiências da faculdade

\begin{tabular}{|l|c|}
\hline \multicolumn{1}{|c|}{ INDICADOR } & MÉDIA \\
\hline $\begin{array}{l}\text { A Faculdade Espam necessita de uma maior infraestrutura, como } \\
\text { laboratórios, salas de aula, biblioteca, tecnologias etc. }\end{array}$ & 4,41 \\
\hline A Faculdade Espam deve ter mais opções de cursos. & 4,61 \\
\hline A Faculdade Espam é pouco conhecida na comunidade. & 3,05 \\
\hline $\begin{array}{l}\text { A Faculdade Espam não possui um bom corpo docente (equipe de } \\
\text { professores). }\end{array}$ & 2,67 \\
\hline Os preços praticados pela Faculdade Espam são muito elevados. & 3,41 \\
\hline A Faculdade Espam não tem tradição no mercado de educação superior. & 2,82 \\
\hline A Faculdade Espam não está localizada no Plano Piloto. & 3,77 \\
\hline
\end{tabular}

Fica evidenciado que os respondem reconhecem a necessidade de melhoria na infraestrutura física, com média de 4,41 (Intervalo de confiança entre 4,28 a 4,54), como também precisa ampliar o seu catálogo de oferta de cursos, com média de 4,61(Intervalo de confiança entre 4,51 a 4,61), o que evidencia a concordância plena do respondente para a abertura de novos cursos. 
Por outro lado, sobre o conhecimento da faculdade pela comunidade, os respondentes não se posicionam, pois a média de 3,05 (Intervalo de confiança entre 2,88 a 3,21) evidencia que não opinaram ou não quiseram responder.

Quanto ao corpo docente, os respondem corroboram o reconhecimento da qualidade da equipe docente, pois tendem a discordar da afirmativa que a faculdade não possui um bom corpo docente, com média de 2,67 (Intervalo de confiança entre 2,49 a 2,84).

Há uma posição uma tendência em concordar que os preços praticados pela faculdade são elevados, com média de 3,41 (Intervalo de confiança entre 3,25 a 3,58$)$.

Por seu turno, os respondentes não souberam ou não quiseram responder sobre o reconhecimento da tradição da faculdade no mercado, com média de 2,82 (Intervalo de confiança entre 2,66 a 2,98).

Os respondentes identificam como um ponto fraco o fato de a faculdade não estar localizada no Plano Piloto, com média de 3,77 (Intervalo de confiança entre 3,59 a 3,96).

Nesta categoria, há uma percepção do que Zeithaml et al. (1993) definem como os três tipos de expectativas de serviço: o desejado, o adequado, e o previsto. Os clientes têm um nível de serviço desejado e eles esperam receber o que acreditam que compreendem possa ser realizado e que deva ser realizado, como uma infraestrutura melhor e mais opções de cursos. Os clientes também têm um nível mínimo de serviço aceitável e eles percebem que o serviço nem sempre alcança os níveis desejados, sendo este o nível de serviço adequado, como o reconhecimento de que há um corpo docente de qualidade que contribui para superar a deficiência de infraestrutura.

Assim, entre estes dois níveis de serviço há uma zona de tolerância que os clientes estão dispostos a aceitar. Por fim, os clientes têm um nível previsível de serviço, que é o nível de serviço que eles acreditam que a empresa irá executar. 


\subsection{Indicadores que influenciam a clientela na escolha por uma faculdade.}

O Quadro 3 evidencia as médias de cada indicador, o que facilita a interpretação como os respondentes concordam ou discordam das afirmativas relacionadas à percepção das deficiências da faculdade sob a ótica dos respondentes.

Quadro 4 - Média dos indicadores que influenciam a escolha da faculdade

\begin{tabular}{|l|c|}
\hline \multicolumn{1}{|c|}{ INDICADOR } & MÉDIA \\
\hline A qualidade dos cursos da faculdade. & 3,47 \\
\hline O preço praticado. & 3,12 \\
\hline A localização da faculdade, por estar próxima da minha casa. & 4,16 \\
\hline O tempo de atuação da Faculdade Espam no ensino superior. & 3,40 \\
\hline O prestígio da Faculdade Espam na comunidade. & 3,40 \\
\hline $\begin{array}{l}\text { Indicação de amigos, conhecidos ou parentes que estudam ou } \\
\text { estudaram na Faculdade Espam. }\end{array}$ & 3,20 \\
\hline $\begin{array}{l}\text { A campanha publicitária da faculdade (outdoor, cartazes, folders, rádio } \\
\text { ou televisão) }\end{array}$ & 2,87 \\
\hline $\begin{array}{l}\text { O resultado da Faculdade Espam nas avaliações do Ministério da } \\
\text { Educação. }\end{array}$ & 3,28 \\
\hline Foi uma escolha dos meus pais ou parentes. & 1,95 \\
\hline A qualidade do corpo docente (equipe de professores) & 3,35 \\
\hline A infraestrutura oferecida. & 2,76 \\
\hline \begin{tabular}{l} 
Pelos turnos oferecidos. \\
\hline Pelos descontos de pontualidade oferecidos.
\end{tabular} \\
\hline
\end{tabular}

Quanto à qualidade dos cursos como fator de influência para escolha da faculdade, a média de 3,47 (Intervalo de confiança entre 3,32 a 3,62) aponta que há concordância, havendo um reconhecimento da qualidade do ensino ofertado, que impacta na escolha. 
Os respondentes não souberam ou não quiseram responder a respeito da influência dos preços praticados na escolha pela faculdade, com média de 3,12 (Intervalo de confiança entre 2,95 a 3,28).

Porém, há a concordância, com média de 4,16 (Intervalo de confiança entre 4,00 a 4,32), que a localização da faculdade é um fator preponderante à escolha pela faculdade.

Isto evidencia que os alunos buscam comodidade e menor deslocamento de sua residência ou trabalho até a faculdade, indicador que é um diferencial competitivo para as faculdades localizadas em cidades satélites do Distrito Federal.

Por outro lado, fatores como tempo de existência da faculdade como o prestígio da faculdade também influência na escolha, pois ambos os fatores apresentaram média de 3,40 (Intervalo de confiança entre 3,26 a 3,54).

Na visão de Las Casas (2008), o marketing educacional deve ser o esforço de posicionamento/comunicação praticado por instituições de ensino junto ao seu público alvo de seus produtos e serviços. Assim, fica evidente que o marketing educacional da ESPAM pode ser direcionado para reforçar a questão da proximidade com a residência dos estudantes como um diferencial de mercado, sobretudo, pela própria característica dos alunos que são trabalhadores e estudar perto de sua moradia favorece a sua qualidade de vida e deslocamento após o término das aulas.

Por sua vez, os respondentes não souberam ou não quiseram responder sobre os fatores, indicação de amigos e parentes, com média de 3,20 (Intervalo de confiança entre 3.02 a 3.38); campanha publicitária, com média de 2,87 (Intervalo de confiança entre 2,70 a 3.04); e resultado nas avaliações do Ministério da Educação, com média de 3,28 (Intervalo de confiança entre 3,12 a 3,46),

Já a qualidade do corpo docente, com média de 3,35 (Intervalo de confiança entre 3,18 a 3,51) é fator de influência da escolha pela faculdade, sob a ótica da clientela.

Por sua vez, também há concordância como fatores de influência os turnos oferecidos, com média de 3,50 (Intervalo de confiança entre 3,32 a 3,67) e os 
descontos de pontualidade praticados, com média de 3,52 (Intervalo de confiança entre 3,35 a 3,69).

Entretanto, há total discordância de a escolha ter tido influência dos pais ou responsáveis, com média de 1,95 (intervalo de confiança entre 1,78 a 2,13) e os respondentes não souberam ou não quiseram opinar, sobre a influência da infraestrutura na escolha, com média de 2,76 (Intervalo de confiança entre 2,59 a 2,94).

Como Cobra e Braga (2004) afirmam a maioria das faculdades, de forma equivocada, norteiam-se para o produto e não para o cliente, vez que focam no desenvolvimento de cursos com corpo docente qualificado e com currículo reforçado, sem se preocupar com o que efetivamente o aluno deseja. Na IES estudada, fica evidente que a infraestrutura é um ponto que necessita de melhoria e ações de marketing que reforcem a importância da proximidade da faculdade da residência do aluno é um grande diferencial competitivo, essencialmente, para os alunos que são trabalhadores, característica marcante da clientela, pois ganham tempo em deslocamento e para descanso após as aulas.

Assim, como apontam Fornari et al (2009), as IES devem identificar suas oportunidade e ameaças e otimizar as vantagens competitivas frente aos concorrentes.

Por fim, conforme indicam Ikeda e Veludo-de-Oliveira (2006) identificar relações entre as características do produto e os valores pessoais é fundamental para prover programas e produtos com capacidade de criar valor aos públicos da organização, o que é válido também para as instituições educacionais. 


\section{CONCLUSÕES E RECOMENDAÇÕES}

O estudo buscou compreender os fatores que influenciam na escolha por uma faculdade localizada em cidade satélite do Distrito Federal a partir da revisão da literatura sobre marketing, especialmente o marketing educacional.

A pesquisa, por meio da metodologia adotada, teve como público alvo os alunos da Faculdade ESPAM, localizada na cidade de Sobradinho/DF, sendo a amostra de 261 alunos, que responderam ao questionário aplicado, que objetivou identificar os objetivos específicos do trabalho acadêmico que são o perfil socioeconômico da clientela; as necessidades da clientela por educação superior; a percepção da clientela quanto aos valores e imagem da faculdade; as deficiências da faculdade sob a ótica da clientela; e os fatores que influenciam a clientela na escolha por uma faculdade.

Quanto ao perfil socioeconômico, ficou evidente que a clientela é formada por um por um público em sua maioria feminino (70\%), sendo que $73 \%$ dos respondentes têm até 30 anos, o que demonstra um perfil jovem, sendo que $74 \%$ exercem atividade remunerada, $57 \%$ são solteiros, condizente com o perfil do aluno que trabalha para manter os estudos.

Um dado importante é que $58 \%$ dos respondentes têm renda até $R \$$ $2.500,00$, sendo pertencentes à denominada classe C, o que evidencia a tendência de acesso à educação superior por esta parcela da população, especialmente em faculdade localizadas em periferia, com a ESPAM, em busca de melhores condições de vida e ascensão social e econômica.

De forma coerente com o dado anterior, $58 \%$ dos alunos mantêm os estudos com recursos próprios.

Os alunos residem na própria cidade de Sobradinho e Sobradinho II (56\%) e em Planaltina (19\%), sendo importante destacar que $16 \%$ dos alunos residem nos Condomínios, o que demonstra a possibilidade de direcionamento do marketing da faculdade para esta clientela, com maior poder aquisitivo, mas que não estuda em Sobradinho, optando por faculdades tradicionais localizadas no Plano Piloto. 
Quanto às necessidades da clientela conclui-se que a escolha pela faculdade foi de forma consciente e que se deu por cursos que os alunos desejavam. Todavia, os alunos reconhecem que parentes e amigos não estudam na ESPAM por não ter o curso que pretendiam.

Há o reconhecimento da clientela que a faculdade precisa intensificar o seu marketing, vez que concordam que necessita divulgar melhor os seus cursos.

Por seu turno, a melhoria no atendimento administrativo é percebida pelos respondentes, sendo um fator, portanto, que pode contribuir para satisfação com a faculdade, podendo influenciar no endomarketing.

Os respondentes concordam que a faculdade atende às expectativas quanto ao curso como também os prepara para o mercado de trabalho.

Outro ponto que merece destaque é a satisfação do aluno com o corpo docente.

Nesta categoria, ficam evidentes que a satisfação da clientela e o atendimento às suas necessidades são elementos essenciais para que o aluno seja o principal elemento de marketing da faculdade, pois expressa a sua opinião para colegas e parentes, o que fortalece a imagem da faculdade junto à comunidade.

Quanto à imagem e valores da faculdade, os respondentes evidenciaram uma tendência à concordância com alguns indicadores, vez que os intervalos de confiança se aproximam da concordância (média 4).

Assim, é percebida a credibilidade da faculdade, bem como a postura de seriedade, como também uma imagem de instituição de qualidade.

Outro item de relevância é que a ESPAM, sob a ótica dos alunos, é respeitada pela comunidade, sendo que eles indicam a faculdade para amigos e parentes.

Mais uma vez, reforça a importância do aluno como o grande divulgador da faculdade, pois a sua indicação para amigos e parentes é um indicador fundamental para reforçar a imagem e os valores da faculdade junto à comunidade. 
Por outro lado, a percepção sobre as deficiências da faculdade é uma categoria que influencia diretamente o aluno como elemento de divulgação, pois a sua insatisfação impactará negativamente em sua opinião sobre a faculdade.

Fica evidente que a Faculdade ESPAM necessita melhorar a sua infraestrutura. Além disso, de forma incoerente com o item sobre a escolha pelo curso que desejava, o respondente demonstra que a faculdade deveria ter uma variedade maior de cursos em seu catálogo de oferta.

Quanto aos fatores que influenciam na escolha da faculdade, indicadores fundamentais para esta pesquisa, fica evidente que impactam na decisão a qualidade dos cursos, o tempo de atuação e prestígio da faculdade, turnos oferecidos e descontos de pontualidade.

Importante destacar que a escolha foi pessoal, não tendo influência os pais ou parentes.

O ponto de maior destaque na escolha pela faculdade é a sua localização, ou seja, os alunos optam por instituições que estejam próximas de sua residência, o que demonstra que há uma clientela que busca comodidade e qualidade de vida.

Assim, o estudo conseguiu atender aos objetivos propostos, vez que evidenciou todas as categorias definidas, com a percepção dos alunos, especialmente quanto aos fatores que influenciam na sua escolha pela faculdade.

Percebe-se que o cliente destaca elementos essenciais para escolha como qualidade dos cursos, corpo docente, política de preços (descontos) e, sobretudo, a localização da faculdade.

Como o perfil do aluno evidenciou que a clientela é formada, em sua maioria, por jovens (até 30 anos) solteiros, que são trabalhadores e que mantém os seus próprios estudos é bem coerente a influência da localização da faculdade na escolha, pois ao retornarem do trabalho vão para a faculdade e após as aulas conseguirão se deslocar mais rapidamente para a sua residência.

Dessa forma, recomenda-se que a faculdade direcione as suas campanhas publicitárias destacando a comodidade em estudar em uma faculdade próxima de sua moradia. 
A pesquisa evidenciou uma deficiência na sua infraestrutura como a necessidade de melhoria em seus serviços administrativos, indicadores que devem merecer atenção da gestão da faculdade como pontos que precisam de maior atenção para minimizar estes pontos fracos.

O estudo limitou-se a estudar apenas uma faculdade, o que dificulta uma possível generalização dos resultados, podendo ser realizadas outras pesquisas em um número maior de instituições, podendo ser comparados resultados, permitindo uma análise mais aprofundada, mas contribui para reflexão sobre os fatores que impactam na escolha por uma faculdade.

Conclui-se, por fim, que a Faculdade ESPAM necessita reforçar seus pontos fracos, mas tem como diferencial competitivo a sua localização, possuindo, também o reconhecimento da clientela da sua imagem e valor, como da qualidade dos cursos e do corpo docente. 


\section{REFERÊNCIAS}

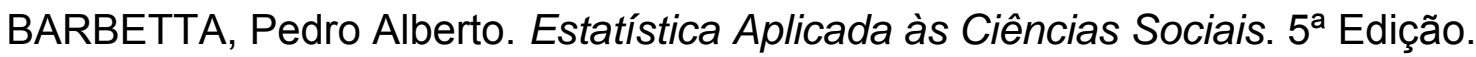
Florianópolis: Editora da UFSC, 2002

BRYMAN, A. Social Research Methods. Oxford University Press, 2008.

COBRA, M; BRAGA, R. Marketing educacional: ferramentas de gestão para instituições de ensino. São Paulo: Cobra Ediotra e Marketing \& Hoper Editora, 2004.

COLOMBO, S. N. Marketing educacional em ação: estratégias e ferramentas. Porto Alegre: Artmed/Bookman, 2005.

D'ANGELO, A. C.. A ética no marketing. Revista de Administração Contemporânea. v. 7, n. 4, Out./Dez. 2003: 55-75. Disponível em:

http://www.scielo.br/scielo.php?script=sci arttext\&pid=S141565552003000400004\&/ ng=pt\&nrm=iso\&tlng=pt. Acesso em: 14 Mar. 2010.

DE TONI, D.; SCHULER, M.. . Gestão da imagem: desenvolvendo um instrumento para a configuração da imagem de produto. Revista de Administração Contemporânea. v.11 n.4 Curitiba out./dez. 2007. Disponível em: http://www.scielo.br/scielo.php?pid=S141565552007000400007\&script=sci arttext\&tl ng=en. Acesso em: 14 Mar. 2010.

ETZEL,M. J; WALKER, J. W.; STANTOS, W. J. Marketing. São Paulo: Makron Books, 2001.

FORNARI, J.S., GIULIANI, A.C., SACOMANO NETO, M., SILVA, E.C.C., CARMARGO, S.H.C.R.V. A importância do planejamento de marketing em instituições de ensino superior: estudo de caso em uma instituição privada. Revista Eletrônica de Gestão de Negócios. v. 5, n. 2, abr.-jun./2009, p. 147-179. Disponível em: http://www.unisantos.br/mestrado/gestao/egesta/artigos/181.pdf. Acesso em: 14 Mar. 2010.

GIL, Antônio Carlos. Como elaborar projetos de pesquisa. São Paulo: Atlas, 2006.

GRACIOSO, F. Marketing estratégico: planejamento estratégico orientado para o mercado. São Paulo: Atlas, 2001. 
HAYES, T. Delphi study of the future of marketing of higher education. Journal of Business Research 60 (2007) 927-931.

IKEDA, A. A., VELUDO-DE-OLIVEIRA, T. M.. Valores em serviços educacionais. Revista Administração de Empresas - RAE-Eletrônica. v. 5, n. 2, Art. 12, jul./dez. 2006. Disponível em:

http://www.rae.com.br/eletronica/index.cfm?FuseAction=Artigo\&ID=3403\&Secao=AR TIGOS\&Volume=5\&Numero=2\&Ano=2006. Acesso em: 14 Mar. 2010.

KOTLER, P.; KELLER, K.L. Administração de Marketing. São Paulo: Pearson Prentice Hall, 2006.

LITWIN, M.S., How to measure survey reliability and validity, Sage Publications, Inc, Survey Kit. 7, 1995.

LAS CASAS, A. L. Marketing educacional: da educação infantil ao ensino superior no contexto brasileiro. São Paulo: Saint Paul Editora, 2008.

LOVERLOCK, C.; WIRTZ, J. Marketing de Serviços: pessoas, tecnologia e resultados. São Paulo: Pearson Prentice Hall, 2006.

MAGALHÃES, F. M.; SAMPAIO, R. Planejamento de marketing; conhecer, decidir e agir - do planejamento estratégico ao operacional. São Paulo: Pearson Prentice Hall,2007.

MARCONI, Marina de Andrade; LAKATOS, Eva Maria. Metodologia científica. São Paulo : Editora Atlas, 2004.

ROESCH, S. M. A. Projetos de estágio e de pesquisa em administração: guia para estágios, trabalhos de conclusão, dissertações e estudos de casos. São Paulo: Atlas, 2007.

TIBOLA, F., VIEIRA, V. A. Pesquisa qualitativa em marketing e suas variações: trilhas para pesquisas futuras. Revista de Administração Contemporânea. v. 9, n. 2, Abr./Jun. 2005: 09-33. Disponível em:

http://www.scielo.br/scielo.php?script=sci arttext\&pid=S141565552005000200002\&I ng=pt\&nrm=iso\&tlng=pt. Acesso em: 14 Mar. 2010.

VOSS, R.; GRUBER, T; SZMIGIN, I. Service quality in higher education: The role of student expectations. Journal of Business Research 60 (2007) 949-959. 
ZEITHAML, V. A.; BERRY, L. L;, PARASURAMAN; A. The nature and determinants of customer expectations of services. J Academy Mark Science 1993;21 (1):1-12. 


\section{APÊNDICE}

Prezado (a) Colega,

\section{QUESTIONÁRIO}

Sou aluno do Curso de Administração a distância da Universidade de Brasília e encontro-me na fase de elaboração da monografia.

Escolhi a Faculdade Espam como objeto de estudo sobre marketing educacional e, para tanto, necessito de sua participação respondendo este questionário para que eu possa realizar a análise dos fatores que influenciam os alunos na escolha por uma faculdade.

Certamente, a sua contribuição será fundamental para a realização da pesquisa e comprometo-me manter a integridade dos dados, bem como o sigilo das informações.

Certo de sua colaboração, agradeço antecipadamente.

José Sérgio de Jesus

\section{QUESTIONÁRIO}

\section{$1^{\text {a. }}$ Seção}

Para responder as questões abaixo, marque com um $X$ no espaço referente ao número que melhor expressa sua opinião, de acordo com a escala abaixo:

As questões a seguir referem-se aos fatores que influenciam a escolha por uma faculdade. Escolha uma das categorias abaixo que melhor expressa a sua opinião;

\begin{tabular}{|l|l|l|l|l|}
\hline \multicolumn{1}{|c|}{$\mathbf{1}$} & \multicolumn{1}{|c|}{$\mathbf{2}$} & \multicolumn{1}{c|}{$\mathbf{3}$} & \multicolumn{1}{c|}{$\mathbf{4}$} & \multicolumn{1}{c|}{$\mathbf{5}$} \\
\hline $\begin{array}{l}\text { Discordo } \\
\text { totalmente }\end{array}$ & $\begin{array}{l}\text { Discordo em } \\
\text { parte }\end{array}$ & $\begin{array}{l}\text { Não sei ou não } \\
\text { quero } \\
\text { responder }\end{array}$ & $\begin{array}{l}\text { Concordo em } \\
\text { parte }\end{array}$ & $\begin{array}{l}\text { Concordo } \\
\text { totalmente }\end{array}$ \\
\hline
\end{tabular}

a) Sobre a necessidade da clientela

\begin{tabular}{|c|c|c|c|c|c|c|}
\hline A1 & $\begin{array}{l}\text { Escolhi a Faculdade Espam por falta de } \\
\text { opção. }\end{array}$ & 1 & 2 & 3 & 4 & 5 \\
\hline $\mathrm{A} 2$ & $\begin{array}{l}\text { Escolhi a Faculdade Espam por ter o curso } \\
\text { que eu desejava. }\end{array}$ & 1 & 2 & 3 & 4 & 5 \\
\hline A3 & $\begin{array}{l}\text { Tenho amigos, conhecidos e parentes que } \\
\text { não estudam na Faculdade Espam por não } \\
\text { ter o curso que desejam. }\end{array}$ & 1 & 2 & 3 & 4 & 5 \\
\hline
\end{tabular}




\begin{tabular}{|c|c|c|c|c|c|c|}
\hline A4 & $\begin{array}{l}\text { A Faculdade Espam precisa divulgar melhor } \\
\text { os seus cursos. }\end{array}$ & 1 & 2 & 3 & 4 & 5 \\
\hline A5 & $\begin{array}{l}\text { Sinto-me satisfeito com os serviços de } \\
\text { atendimento administrativo ao } \\
\text { (Secretaria, Tesouraria) prestados pela } \\
\text { Faculdade Espam. }\end{array}$ & 1 & 2 & 3 & 4 & 5 \\
\hline A6 & $\begin{array}{l}\text { A Faculdade Espam precisa melhorar o seu } \\
\text { atendimento administrativo. }\end{array}$ & & & & & \\
\hline A7 & $\begin{array}{l}\text { O curso que freqüento tem atendido às } \\
\text { minhas expectativas relacionadas à } \\
\text { qualidade do ensino. }\end{array}$ & 1 & 2 & 3 & 4 & 5 \\
\hline A8 & $\begin{array}{l}\text { O curso tem me preparado para o mercado } \\
\text { de trabalho. }\end{array}$ & 1 & 2 & 3 & 4 & 5 \\
\hline A9 & $\begin{array}{l}\text { Os preços praticados pela Faculdade Espam } \\
\text { estão de acordo com as minhas } \\
\text { possibilidades financeiras. }\end{array}$ & 1 & 2 & 3 & 4 & 5 \\
\hline A10 & $\begin{array}{l}\text { O Corpo docente (equipe de professores) } \\
\text { demonstra preparação para o cargo. }\end{array}$ & 1 & 2 & 3 & 4 & 5 \\
\hline A11 & Eu mesmo (a) custeio os meus estudos. & 1 & 2 & 3 & 4 & 5 \\
\hline A12 & $\begin{array}{l}\text { São meus pais ou parentes que custeiam os } \\
\text { meus estudos. }\end{array}$ & 1 & 2 & 3 & 4 & 5 \\
\hline
\end{tabular}

b) Sobre a percepção quanto à imagem e valores da Faculdade Espam

\begin{tabular}{|l|l|l|l|l|l|l|}
\hline B1 & A Faculdade Espam desperta credibilidade. & 1 & 2 & 3 & 4 & 5 \\
\hline B2 & $\begin{array}{l}\text { A Faculdade Espam mantém uma postura de } \\
\text { seriedade. }\end{array}$ & 2 & 3 & 4 & 5 \\
\hline B3 & $\begin{array}{l}\text { A Faculdade Espam possui uma imagem de } \\
\text { instituição de qualidade. }\end{array}$ & 2 & 3 & 4 & 5 \\
\hline B4 & $\begin{array}{l}\text { Sinto orgulho de estudar na Faculdade } \\
\text { Espam. }\end{array}$ & 1 & 2 & 3 & 4 & 5 \\
\hline B5 & $\begin{array}{l}\text { Considero a Espam a melhor a faculdade da } \\
\text { cidade. }\end{array}$ & 1 & 2 & 3 & 4 & 5 \\
\hline B6 & $\begin{array}{l}\text { Percebo que a Faculdade Espam demonstra } \\
\text { compromisso com o aluno. }\end{array}$ & 2 & 3 & 4 & 5 \\
\hline B7 & $\begin{array}{l}\text { A Faculdade Espam tem o respeito da } \\
\text { comunidade. }\end{array}$ & 1 & 3 & 4 & 5 \\
\hline B8 & $\begin{array}{l}\text { Indico a Faculdade Espam para amigos, } \\
\text { conhecidos e parentes. }\end{array}$ & 2 & 3 & 4 & 5 \\
\hline
\end{tabular}

c) Sobre as deficiências percebidas da Faculdade Espam

\begin{tabular}{|l|l|l|l|l|l|l|}
\hline C1 & $\begin{array}{l}\text { A Faculdade Espam necessita de uma maior } \\
\text { infraestrutura, como laboratórios, salas de } \\
\text { aula, biblioteca, tecnologias etc. }\end{array}$ & 2 & 3 & 4 & 5 \\
\hline C2 & $\begin{array}{l}\text { A Faculdade Espam deve ter mais opções de } \\
\text { cursos. }\end{array}$ & 1 & 2 & 3 & 4 & 5 \\
\hline C3 & $\begin{array}{l}\text { A Faculdade Espam é pouco conhecida na } \\
\text { comunidade. }\end{array}$ & 1 & 3 & 4 & 5 \\
\hline C4 & $\begin{array}{l}\text { A Faculdade Espam não possui um bom } \\
\text { corpo docente (equipe de professores). }\end{array}$ & 1 & 2 & 3 & 4 & 5 \\
\hline C5 & Os preços praticados pela Faculdade Espam & 1 & 2 & 3 & 4 & 5 \\
\hline
\end{tabular}




\begin{tabular}{|l|l|l|l|l|l|l|}
\hline & são muito elevados. & & & & & \\
\hline C6 & $\begin{array}{l}\text { A Faculdade Espam não tem tradição no } \\
\text { mercado de educação superior. }\end{array}$ & 2 & 3 & 4 & 5 \\
\hline C7 & $\begin{array}{l}\text { A Faculdade Espam não está localizada no } \\
\text { Plano Piloto. }\end{array}$ & 2 & 3 & 4 & 5 \\
\hline
\end{tabular}

d) Sobre os fatores que influenciaram minha a escolha pela Faculdade Espam.

\begin{tabular}{|c|c|c|c|c|c|c|}
\hline D1 & A qualidade dos cursos da faculdade. & 1 & 2 & 3 & 4 & 5 \\
\hline D2 & O preço praticado. & 1 & 2 & 3 & 4 & 5 \\
\hline D3 & $\begin{array}{l}\text { A localização da faculdade, por estar } \\
\text { próxima da minha casa. }\end{array}$ & 1 & 2 & 3 & 4 & 5 \\
\hline D4 & $\begin{array}{l}\text { O tempo de atuação da Faculdade Espam } \\
\text { no ensino superior. }\end{array}$ & 1 & 2 & 3 & 4 & 5 \\
\hline D5 & $\begin{array}{l}\text { O prestígio da Faculdade Espam na } \\
\text { comunidade. }\end{array}$ & 1 & 2 & 3 & 4 & 5 \\
\hline D6 & $\begin{array}{l}\text { Indicação de amigos, conhecidos ou } \\
\text { parentes que estudam ou estudaram na } \\
\text { Faculdade Espam. }\end{array}$ & 1 & 2 & 3 & 4 & 5 \\
\hline D7 & $\begin{array}{l}\text { A campanha publicitária da faculdade } \\
\text { (outdoor, cartazes, folders, rádio ou } \\
\text { televisão) }\end{array}$ & 1 & 2 & 3 & 4 & 5 \\
\hline D8 & $\begin{array}{l}\text { O resultado da Faculdade Espam nas } \\
\text { avaliações do Ministério da Educação. }\end{array}$ & 1 & 2 & 3 & 4 & 5 \\
\hline D9 & $\begin{array}{l}\text { Foi uma escolha dos meus pais ou } \\
\text { parentes. }\end{array}$ & 1 & 2 & 3 & 4 & 5 \\
\hline D10 & $\begin{array}{l}\text { A qualidade do corpo docente (equipe de } \\
\text { professores) }\end{array}$ & 1 & 2 & 3 & 4 & 5 \\
\hline D11 & A infraestrutura oferecida. & 1 & 2 & 3 & 4 & 5 \\
\hline D12 & Pelos turnos oferecidos. & 1 & 2 & 3 & 4 & 5 \\
\hline D13 & $\begin{array}{l}\text { Pelos descontos de pontualidade } \\
\text { oferecidos. }\end{array}$ & 1 & 2 & 3 & 4 & 5 \\
\hline D14 & Pelas bolsas de estudos disponíveis. & 1 & 2 & 3 & 4 & 5 \\
\hline
\end{tabular}

\section{$2^{a}$ Seção}

Nas questões a seguir, por favor, marque com um $\mathrm{X}$ apenas uma alternativa

Qual a sua idade?

( ) até 20 anos ( ) de 21 a 25 anos ( ) de 26 a 30 anos ( ) de 31 a 35 anos

( ) de 36 a 40 anos ( ) acima de 40 anos

Qual o seu sexo?

( ) Masculino ( )Feminino

Você trabalha ou faz estágio?

( ) Sim ( ) Não 
Onde você reside?

( ) Sobradinho ( ) Sobradinho II ( ) Planaltina () Condomínios
( ) Planaltina de Goiás ( ) Paranoá ( ) Taquari ( ) Outro

Qual seu estado civil?

( ) Solteiro ( ) Casado ( ) Divorciado ( ) União estável （）Viúvo

Qual a sua renda familiar?

（） até $\mathrm{R} \$ 1.000,00 \quad(\quad)$ de $\mathrm{R} \$ 1.001,00$ a $\mathrm{R} \$ 2.500,00$

( ) de $\mathrm{R} \$ 2.501,00$ a $\mathrm{R} \$ 4.000,00$ ( ) de $\mathrm{R} \$ 4.001,00$ a $\mathrm{R} \$ 6.000,00$

( ) acima de $\mathrm{R} \$ 6.000,00$

Como está sendo mantido o seu curso? ( ) Recursos próprios

( ) recursos dos pais ( ) recursos de outros parentes $($ ) bolsa de estudos ( ) outros especificar.

Obrigado pela participação! 